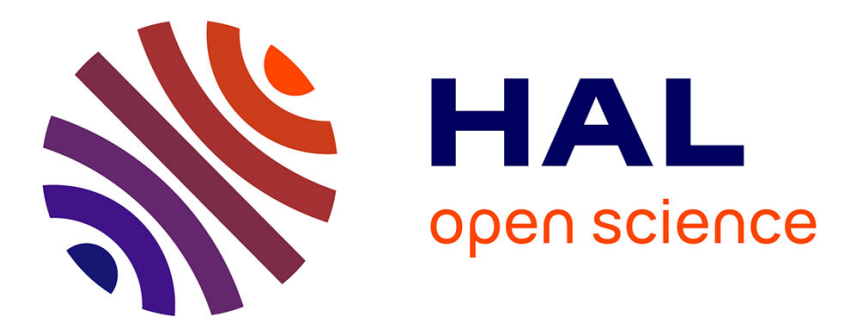

\title{
Nutrient dynamics in a chronosequence of douglas-fir (Pseudotsuga menziesii (Mirb.) Franco) stands on the Beaujolais mounts (France). 2. Quantitative approach
}

\author{
Renato Marques, Jacques J. Ranger, Sylvain Villette, André Granier
}

\section{- To cite this version:}

Renato Marques, Jacques J. Ranger, Sylvain Villette, André Granier. Nutrient dynamics in a chronosequence of douglas-fir (Pseudotsuga menziesii (Mirb.) Franco) stands on the Beaujolais mounts (France). 2. Quantitative approach. Forest Ecology and Management, 1997, 92 (1-3), pp.167-197. 10.1016/S0378-1127(96)03913-8 . hal-02685561

\section{HAL Id: hal-02685561 \\ https://hal.inrae.fr/hal-02685561}

Submitted on 1 Jun 2020

HAL is a multi-disciplinary open access archive for the deposit and dissemination of scientific research documents, whether they are published or not. The documents may come from teaching and research institutions in France or abroad, or from public or private research centers.
L'archive ouverte pluridisciplinaire HAL, est destinée au dépôt et à la diffusion de documents scientifiques de niveau recherche, publiés ou non, émanant des établissements d'enseignement et de recherche français ou étrangers, des laboratoires publics ou privés. 


\title{
Nutrient dynamics in a chronosequence of Douglas-fir (Pseudotsuga menziesii (Mirb). Franco) stands on the Beaujolais Mounts (France). 2. Quantitative approach
}

\author{
Renato Marques, Jacques Ranger *, Sylvain Villette, André Granier \\ INRA-Centre de Nancy, Equipe Cycles Biogeochimiques, Champenoux, 54280 Seichamps, France
}

Accepted 5 August 1996

\begin{abstract}
Nutrient fluxes were determined in a chronosequence of Douglas-fir stands in the Beaujolais Mounts (France). Annual and seasonal variations occurred during the 3 years of investigation; fluxes were generally highest in autumn-winter.

Atmospheric inputs were among the mean values from a monitoring network of forest ecosysterns in France. Nutrient outputs from the soil profile were higher than average and occurred mainly during vegetation dormancy.

Mean input-output budgets were negative for $\mathrm{N}, \mathrm{S}, \mathrm{K}, \mathrm{Ca}$ and $\mathrm{Mg}$, characterising an imbalance of the site chemistry dynamics. The $\mathrm{P}$ budget was positive. Most of the nutrient output from the ecosystem occurred as losses in the drainage water. These losses were related to excess nitrification and consecutive cation mobilisation throughout the soil profile.

Surface water, however, had a neutral $\mathrm{pH}$ and very low nitrate and aluminium contents, which may have been buffered by the subsoil.

Budgets differed between stands and tended to be more negative in the youngest stand. Part of this behaviour was related to stand age and part to the former land use of plots. Theoretical budgets were calculated for forest rotation lengths of 20,40 and 60 years; it was concluded that shorter rotations would increase nutrient losses. The trend of a decrease in budget deficits with stand age suggests that the effect of vegetation change will be reduced at the next rotation but the impact of stand development may remain.

Predicted nutrient budgets for a second 60 year Douglas-fir rotation suggested that available $\mathrm{Ca}$ in the soil would be depleted and that this depletion would be even more drastic if whole tree harvesting were adopted.

In conclusion, Douglas-fir stands introduced changes in soil function that may impoverish the soil if present trends remain the same over the next forest rotations. The maintenance of sustainability will require nutrient input by fertilisation.
\end{abstract}

Kevwords: Douglas-fir; Nutrients; Biogeochemical cycle; Input-output budgets; Dynamics; Chronosequence; Gravitational soil solutions

Corresponding author. Tel.: 3383394068 ; fax: 3383394069. 


\section{Introduction}

Douglas-fir was first introduced in France 150 years ago. It is presently one of the most intensively planted species in the country owing to its high potential for wood production and its well appreciated wood quality.

Sustainable management of these stands needs to be demonstrated, not only in terms of maintaining the present forest production level but also with respect to maintaining soil fertility and surface water quality. "Wise management of production forests is essential if we are to ensure that future generations will be able to derive the same, if not more. resources from the land than were derived by preceding generations"' (Beets et al., 1994).

Land occupation by new vegetation may result in dramatic changes in soil dynamics (Page, 1970; Feger, 1988; Ranger and Nys, 1994). Thus, a research programme was initiated in 1991 by selecting a chronosequence of Douglas-fir stands able to represent ecosystem dynamics throughout a whole forest rotation.

The first results described the dynamics of biomass and nutrient accumulation in the stand (Ranger et al., 1995). Relevant conclusions were obtained by comparing Douglas-fir with other species or by testing different silvicultural scenarios, i.e. changing the rotation length or changing the intensity of forest harvesting. Nutrient fluxes through the ecosystem were then investigated to calculate the input-output budget of the ecosystem. The first step was to qualify the chemistry of solutions transferred within these Douglas-fir stands and the processes involved in the acquisition of the chemistry and on the dynamics of these solutions (Marques and Ranger, 1996).

The objective of the present paper is to quantify the main fluxes of the biogeochemical cycle in the forest stands and to establish input-output budgets for individual stands and for different lengths of forest rotation. The results are discussed by focusing on the possible impact of Douglas-fir on soil and surface water quality.

\section{Materials and methods}

Only the essentials are indicated here as a detailed description of the site and instruments has already been published in a companion paper (Marques and Ranger. 1996).

\subsection{Site characterisation}

Three stands aged 20,40 and 60 years representing a forest chronosequence were chosen on the Beaujolais Mounts in France $\left(46^{\circ} 30^{\prime} \mathrm{N}, 4^{\circ} 38^{\prime} \mathrm{E}\right)$.

Stand characteristics were: 922,350 and 225 trees $\mathrm{ha}^{-1} ; 14.3,28.2$ and $36.3 \mathrm{~m}$ average height; 18.1. 33.3 and $52.1 \mathrm{~cm}$ average DBH; 250.670 and 1100 $\mathrm{m}^{3} \mathrm{ha}^{-1}$ average volume of total stemwood. The 20and 40-year-old stands presented no understorey; the understorey of the 60-year-old stand was mainly composed of blackberry (Rubus fruticosus L.). The nutrient content and mean current immobilisation of stands (excluding understorey) is summarised in Table 1 (Ranger et al.. 1995). Mean root distribution for the three stands is as follows: $33 \%$ in the $0-15$ $\mathrm{cm}$ layer, $25 \%$ in the $15-30 \mathrm{~cm}$ layer. $28 \%$ in the $30-60 \mathrm{~cm}$ layer and $14 \%$ below $60 \mathrm{~cm}$.

The site has an elevation of $750 \mathrm{~m}$, a mean annual temperature of $7^{\circ} \mathrm{C}$ and mean annual rainfall of 1000 $\mathrm{mm}$, which is more or less evenly distributed throughout the year with a slight maximum in summer.

\subsection{Soil characterisation}

Soils were typic Dystrochrepts (Soil Survey Staff, 1975). Soil texture was loam (40- and 60-year-old stands) and silt-loam (20-year-old stand) in the top $80 \mathrm{~cm}$ layer, and loam (all stands) in the deepest horizons. The organic matter content of the upper soil horizons was rather high in all stands and somewhat higher in the 20-year-old stand. Organic nitrogen followed the same tendency. Total $\mathrm{Ca}$ and $\mathrm{Mg}$ were somewhat higher and $\mathrm{K}$ lower in the soil of the 20 -year-old stand than in the older stands. The $\mathrm{pH}$ showed no differences between stands. The young stand had higher exchangeable $\mathrm{Ca}^{2+}$ and $\mathrm{Mg}^{2+}$ concentrations in the upper soil horizons than the other stands but also higher concentrations of exchangeable $\mathrm{Al}^{3+}$. The 'base' cation saturation in the deepest soil layers was highest in the 20-year-old stand.

The storage of total and of available elements in the organic and mineral soil are presented in Table 1. 


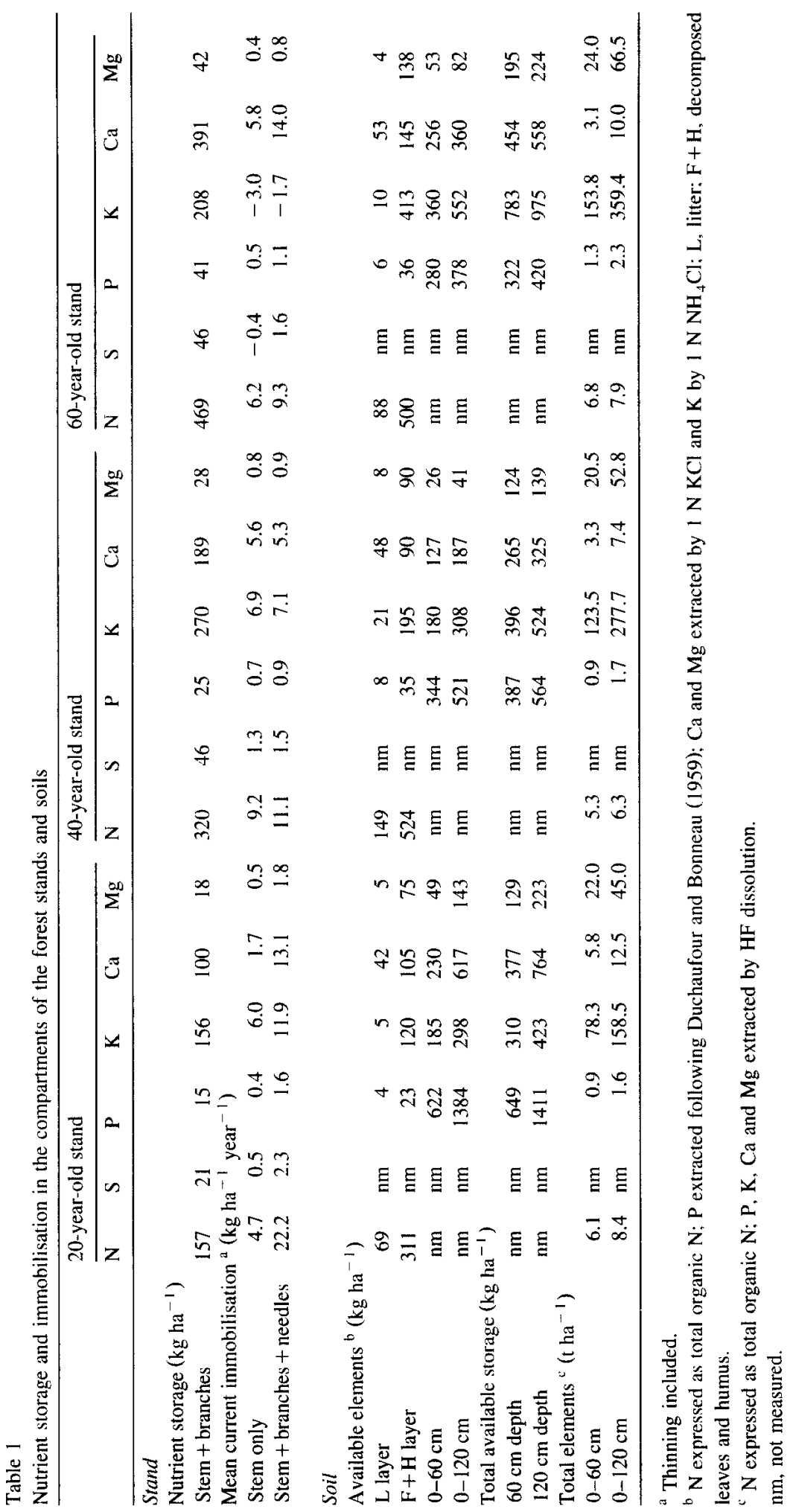




\subsection{Measurement of atmospheric input and seepage water}

Nutrient fluxes were measured in four compartments of the ecosystem following the classical model for forest plot studies. Compartments were: (i) open area, (ii) canopy, (iii) forest floor and (iv) soil (subdivided into four layers in the 40- and 60-year-old stands, and into three layers in the 20-year-old stand).

Daily bulk precipitation in the open area $(P t)$ was collected by an automatic rain gauge. Flux through the canopy was considered to be total throughfall plus stemflow (TS), which were sampled, respectively, by double gutters under the canopy (three replicates per plot) and collars around tree trunks (ten replicates per plot). Stemflow was locally large and often overflowed containers (60-120 1), but it only represented $3 \%$ of $T S$ when the total plot area was considered. Forest floor solutions $(F F)$ were collected by three sets of nine narrow lysimeters. Gravitational soil solutions from $15 \mathrm{~cm}(\mathrm{P}-15), 30$ $\mathrm{cm}$ (P-30), $60 \mathrm{~cm}$ (P-60) and $120 \mathrm{~cm}$ depth (P-120) were sampled by zero-tension plate lysimeters (four replicates per level) in the 40- and 60-year-old stands and only from the top three levels in the 20-year-old stand.

Collection and measurements started in July 1992 and ended in June 1995.

\subsection{Solution analyses}

After volume measurement and sampling, the solutions were carried to the laboratory, filtered $(0.45$ $\mu \mathrm{m})$, maintained at $4^{\circ} \mathrm{C}$ and analysed as quickly as possible. Measurements of $\mathrm{pH}$ were made with a single-rod $\mathrm{pH}$ electrode (XEROLIT ${ }^{\circledR}$ ) connected to a Mettler DL21 pH meter. Nitrate, ammonium and chloride were measured by colorimetry (Technicon autoanalyser II) and total Si, S, P, K, Ca, Mg, Mn, $\mathrm{Na}, \mathrm{Fe}$ and $\mathrm{Al}$ by ICP emission spectroscopy (JY 38 Plus spectrometer). Total organic carbon (TOC) was measured during the first year on an TCM 480 (Erba Science) apparatus and subsequently on a TOC 5050 (Shimadzu).

\subsection{Water fluxes}

Fluxes in the first two compartments, $P t$ and $T S$, were directly availahle from field measurements.
Fluxes through the forest floor and within the soil, which were measured by lysimeters. were inadequate for estimating soil water seepage because it was not possible to determine the volume of soil actually drained by the lysimeters.

A water flux model (Villette, 1994) was then used to quantify fluxes through the ecosystem. This model was first developed by Breda (1994). Daily rainfall was available from field measurements: model fluxes were estimated daily and cumulated over a 4 week period to coincide with the water chemistry data. Assumptions for model calculations were mainly based on earlier investigations by Aussenac and Boulangeat (1980) and Granier (1987). Parametrisation was adapted to the present study according to the structure of stands and to the local climate conditions.

The general equation of the model is

$P t=I n+T R+E T_{\mathrm{u}}+\Delta S_{\mathrm{sil}}+D R$

where $P t$ is incident precipitation, $I n$ is canopy interception, $T R$ is transpiration of trees, $E T_{\mathrm{u}}$ is evapotranspiration of the understorey, $\Delta S_{\mathrm{soil}}$ is soilwater storage variation and $D R$ is drainage at 60 or $120 \mathrm{~cm}$ depth. Pt was mainly obtained from local measurements but occasionally had to be corrected. using its relationship with throughfall when monthly rainfall was lower than monthly throughfall (this happened during some snow events).

Interception was calculated by the equation

$I n=P_{t}-T S$

$T S$ in the model was estimated by computing throughfall (THR) and stemflow (STF) separately with the following equations calibrated for the stands

$$
\begin{aligned}
& \frac{\mathrm{THR}}{P t}=\frac{0.87 \times(P t-1)^{1.7}}{2.8+(P t-1)^{1.7}} \\
& \frac{\mathrm{STF}}{P t}=\frac{0.025 \times(P t-1)^{3}}{2+(P t-1)^{3}}
\end{aligned}
$$

$T R$ was not measured directly but estimated by the relationship with potential evapotranspiration (PET) calculated from the Penman equation

$$
T R=0.65 \times \mathrm{PET}
$$

The coefficient 0.65 was derived from sap-flow measurements and a water halance obtained on Dou- 
glas-fir stands in the Lorraine region by Aussenac and Boulangeat (1980) and Granier (1987); PET was provided by the Meteorological Station of 'TarareLes Sauvages' situated $50 \mathrm{~km}$ further south at the same elevation. Granier (1987) observed that this coefficient varied with the relative extractable water (REW) in the soil. REW is defined as

$\mathrm{REW}=\frac{\text { extractable soil water }}{\text { maximum available soil water }}$

Maximum available soil water $(W s)$ was defined as $W s=\left(M_{\mathrm{c}}-M_{p F 4.2}\right) \times D_{\mathrm{a}} \times\left(1-S_{\mathrm{p}}\right) \times \rho$

where $M_{\mathrm{c}}$ is soil moisture at field capacity, $M_{p F 4.2}$ is soil moisture at $p F=4.2, D_{\mathrm{a}}$ is apparent density of fine earth, $S_{\mathrm{p}}$ is volumetric proportion of stones and $\rho$ is the density of water $\left(1 \mathrm{~kg} \mathrm{l}^{-1}\right)$.

Under soil water limiting conditions (water stress), $T R$ was assumed to decrease linearly with REW, according to observations made in four Douglas-fir stands (Aussenac and Boulangeat, 1980)

$$
T R=0.65 \times \mathrm{PET} \times \mathrm{REW} / 0.4
$$

The limitation of $T R$ when foliage is wet was also taken into account in the model.

$E T_{\mathrm{u}}$ was estimated for each stand from the estimated global radiation decrease between open area

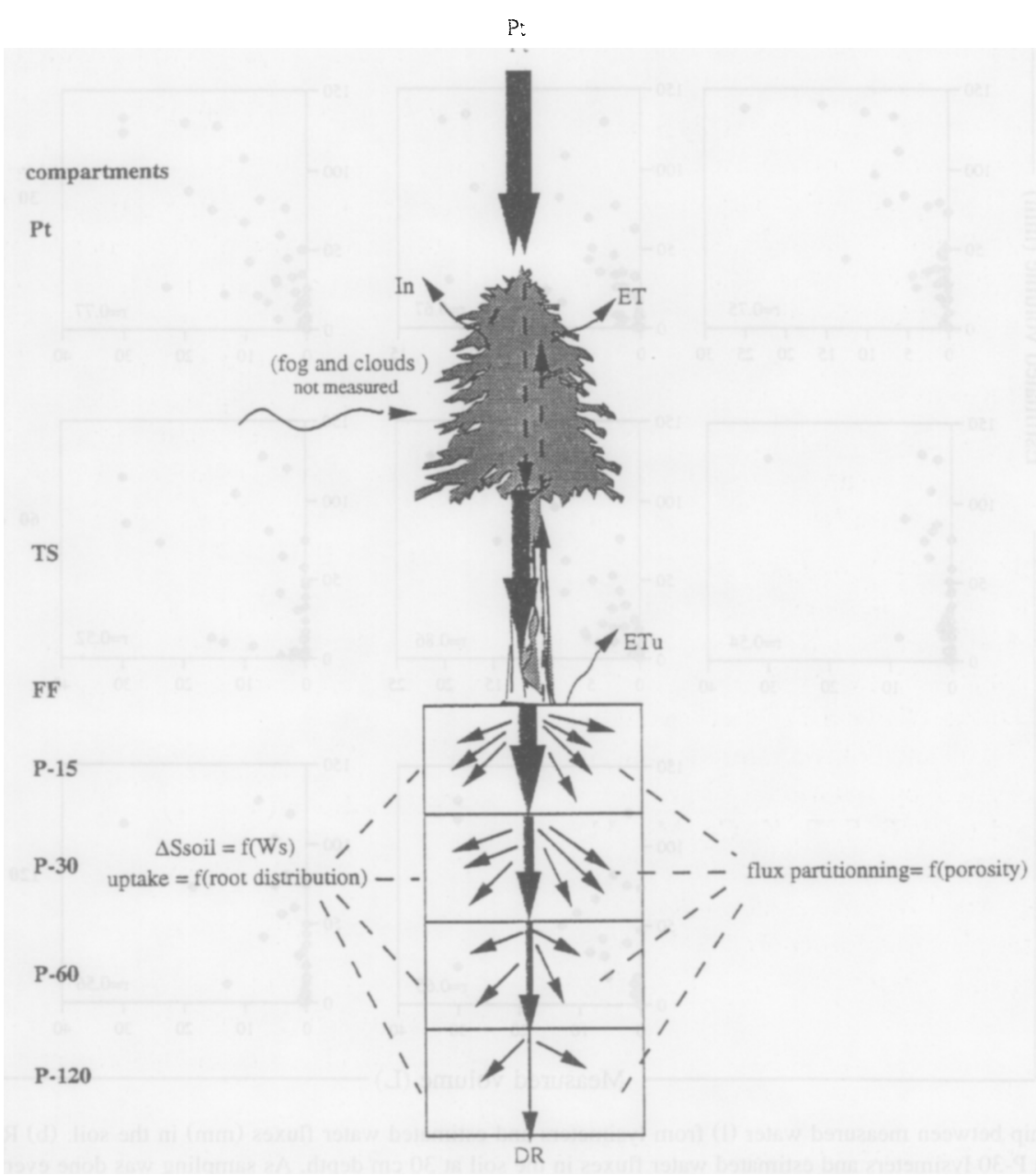

Fig. 1. Schematic water fluxes after the nuodel developed by Villette (1994). 
$\left(R g_{0}\right)$ and under tree cover $\left(R g_{u}\right)$ according to the following formula

$E T_{\mathrm{u}}=\mathrm{PET} \times \frac{R g_{\mathrm{u}}}{R g_{0}} \times \mathrm{REW}_{30}$

$R g_{\mathrm{u}}$ and $R g_{\mathrm{o}}$ were measured with a lux meter;
$\mathrm{REW}_{30}$ is the relative extractable water in the upper $30 \mathrm{~cm}$ soil layer.

Actual evapotranspiration of stands ( $E T)$, which did not appear in the general equation, was calculated as: $E T=T R+E T_{n}+I n$.

$\Delta S_{\text {soil }}$ was the variation of the available water (a)
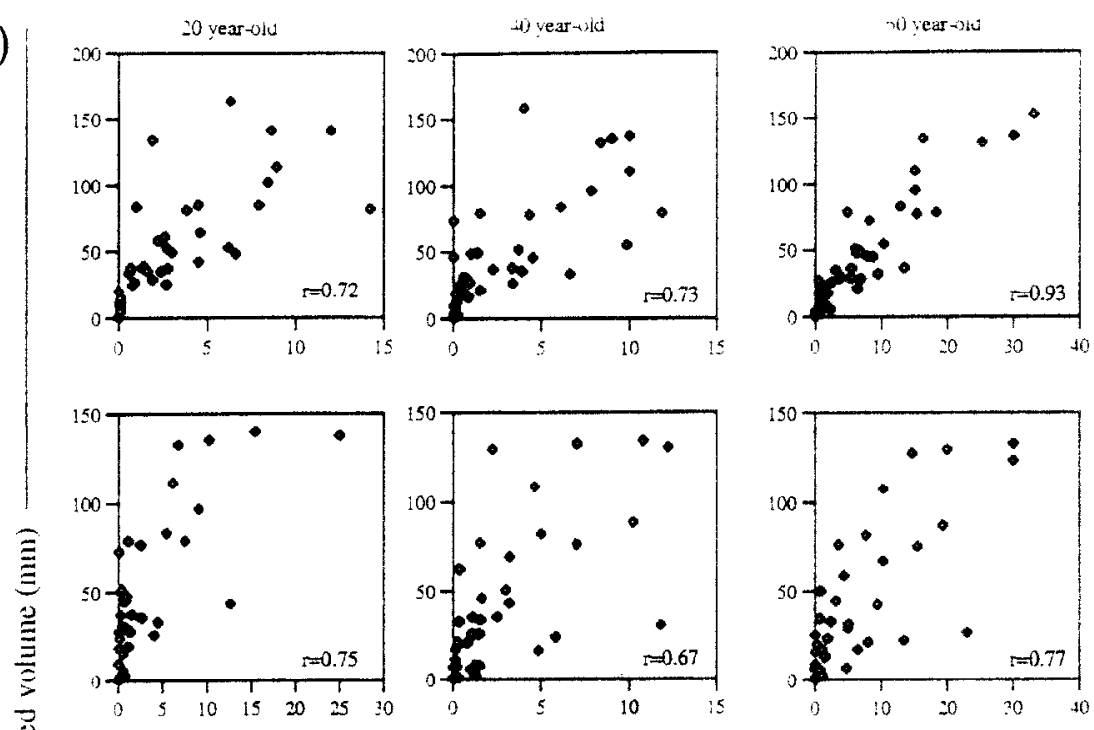

$30 \mathrm{~cm}$
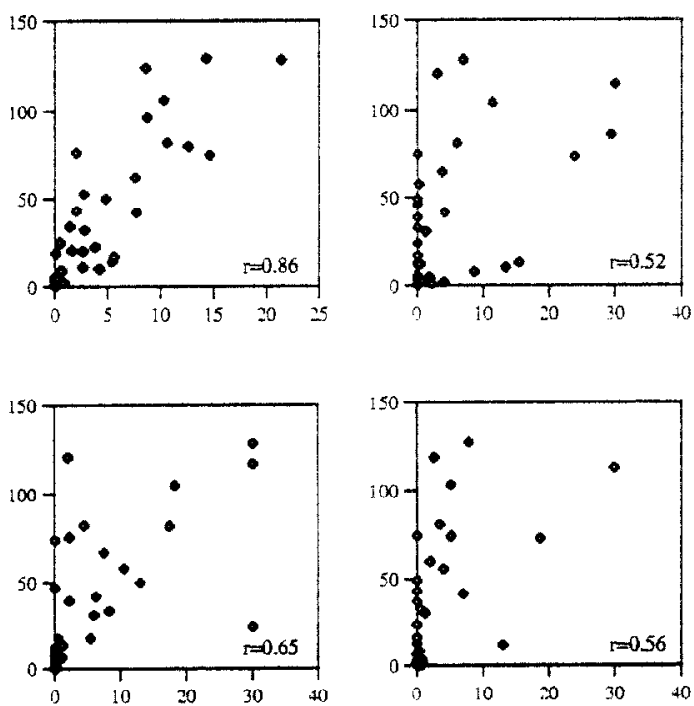

depth

$15 \mathrm{~cm}$

Measured volume (L)

Fig. 2. (a) Relationship between measured water (1) from lysimeters and estimated water fluxes ( $\mathrm{mm}$ ) in the soil. (b) Relationship between measured water from P-30 lysimeters and estimated water fluxes in the soil at $30 \mathrm{~cm}$ depth. As sampling was done every 4 weeks. there are some months where sampling occurred twice. 
(b)
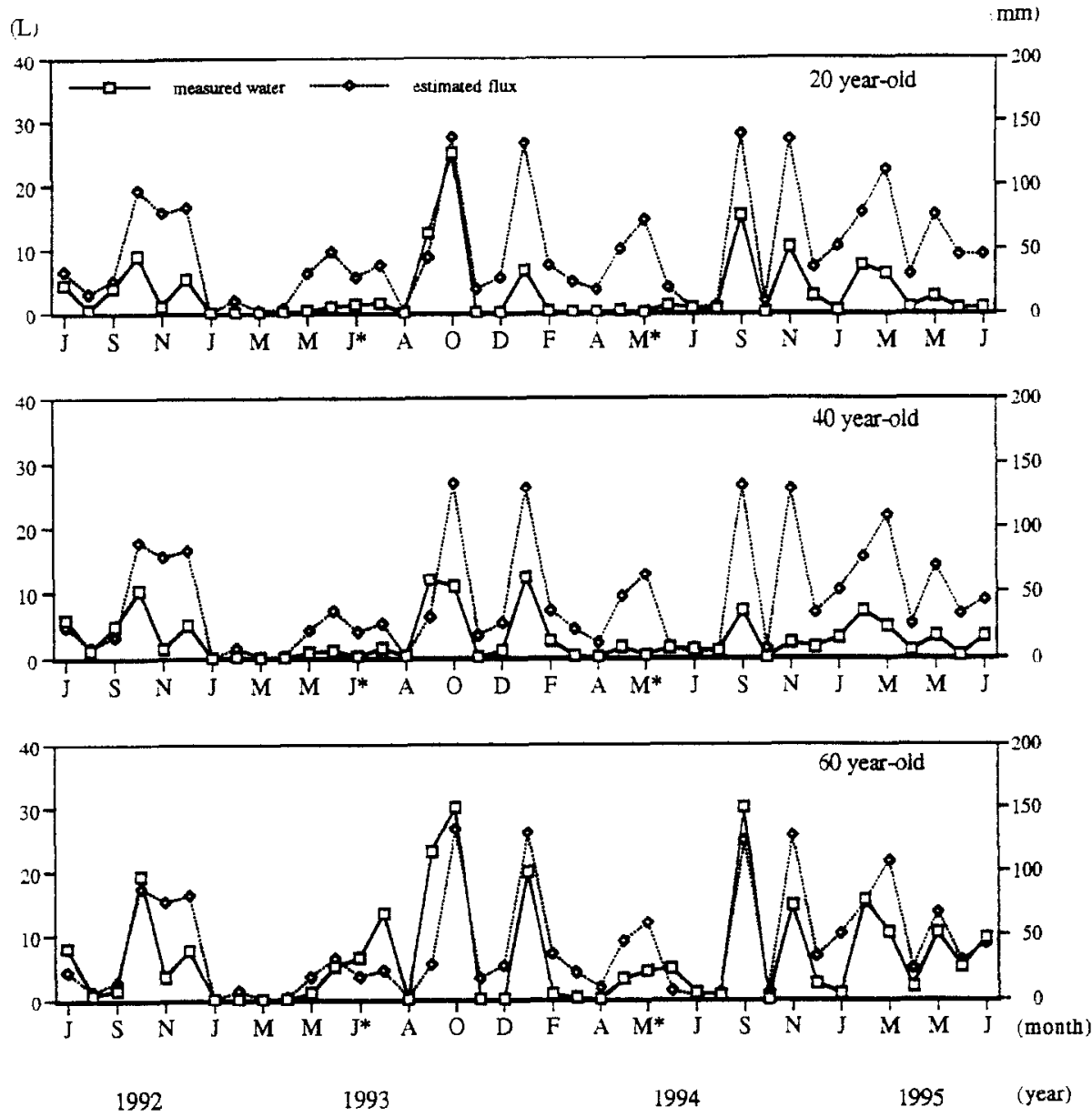

Fig. 2 (continued).

content in each soil layer during the water flux, i.e. final water content minus initial water content.

Water fluxes were calculated by considering each compartment as a black-box and fluxes resulted from the balance between gain and loss in each box (Fig. 1).

Input-output calculations in the overground compartments ( $P t$ and $T S)$ assumed that input equalled $P t$ and output was equal to $I n+E T+E T_{\mathrm{u}}$.

Forest floor water flux was considered as $T S-$ $E T_{\mathrm{u}}$.

Mineral soil was divided into four layers corresponding to the lysimeter depths for characterising individual budgets: $0-15,15-30,30-60$ and $60-120$ $\mathrm{cm}$. Input to the $0-15 \mathrm{~cm}$ soil layer was the drainage flux from forest floor and so on for the next soil layer down to a depth of 60 or $120 \mathrm{~cm}$. Water penetration into each soil horizon was portioned out into a quick flux along the macroporosity and a slow diffusion flux along the microporosity. Water losses by evapotranspiration were assumed to be proportional to the distribution of roots in each soil layer which was evaluated from grid measurements on two soil pits per stand. If the budget was positive then drainage $(D R)$ occurred, if negative then the soil reservoir was being emptied by the plants.

Significant correlation between measured and calculated values of $P t$ and $T S\left(n=37 ; r_{20}=0.95\right.$, $\left.r_{40}=0.97, r_{60}=0.97\right)$ and very close absolute values were observed. Estimated soil water fluxes showed a time pattern variation rather well correlated with water volume obtained from the lysime- 
ters (Fig. 2(a)Fig. 2(b)) but direct comparison of absolute values was not possible. Nevertheless, any errors in the estimations would not affect comparisons between stands since they would apply to all stands equally.

\subsection{Nutrient fluxes}

Element fluxes were obtained by weighting concentrations with the calculated water fluxes from the model. Seasonal and annual fluxes were the total amount of fluxes at the end of each season or year.

Seasons were defined as follows: summer, July to September; autumn, October to December; winter, January to April; spring, May to late June.

\subsection{Partitioning of atmospheric input}

Total atmospheric deposition (TD) to forest ecosystems are separated into wet deposition $(P t)$, dry deposition ( $D D)$, and cloud and fog droplet deposition (Ulrich, 1983; Lovett and Lindberg, 1984). During the 3 years of measurement cloud and fog were considered as negligible; $P t$ solutions, which were sampled as bulk precipitation, were considered as wet deposition in the calculations.

$T D_{x}=P t_{x}+D D_{x} \quad x=$ chemical element

Canopy interaction processes $(\mathrm{C} i)$, i.e. canopy leaching and canopy uptake, alter the solution chemistry down through the canopy and are implicit in throughfall and stemflow measurements.

$T S_{x}=P t_{x}+D D_{x} \pm C i_{x}$

Lack of reliable measurement methods for $D D$ and $\mathrm{Ci}$ fluxes made it necessary to use the calculation approach first described by Ulrich (1983) and adapted here. It was assumed that $C i$ was negligible or did not exist for certain elements (e.g. Na and S) which therefore could be used as tracers for calculating $D D$ for other elements. Unlike Ulrich (1983) and Bredemeier (1988), we did not separate particulate and gas deposition and $\mathrm{S}_{-} \mathrm{SO}_{4}^{2-}$ was used as a tracer in addition to $\mathrm{Na}$. This option was supported by the behaviour of elements in $P t$ solutions. $\mathrm{Na}^{+}$ was better correlated with $\mathrm{H}_{2} \mathrm{PO}_{4}^{-}-\mathrm{P}, \mathrm{K}^{+}, \mathrm{Ca}^{2+}$ and $\mathrm{Mg}^{2+}$, and $\mathrm{SO}_{4}^{2-}-\mathrm{S}$ with $\mathrm{NH}_{4}^{+}-\mathrm{N}$ and $\mathrm{NO}_{3}^{-}-\mathrm{N}$. Thus, $\mathrm{Na}^{+}$was used as a tracer to calculate $D D$ for
$\mathrm{H}_{2} \mathrm{PO}_{4}^{-}-\mathrm{P}, \mathrm{K}^{+}, \mathrm{Ca}^{2+}$ and $\mathrm{Mg}^{2+}$, and $\mathrm{SO}_{4}^{2--} \mathrm{S}$ was the element tracer for $\mathrm{NH}_{4}^{+}-\mathrm{N}$ and $\mathrm{NO}_{3}^{-}-\mathrm{N}$. Dry deposition of $\mathrm{Na}^{+}$and $\mathrm{SO}_{4}^{2-} \mathrm{S}$ was considered as $T S-P t . D D$ for the other elements was calculated with the following equations

$$
\begin{aligned}
D D_{x} & =\left(\frac{T S-P t}{P t}\right)_{\mathrm{Na}} \times P t_{x} \\
x & =\mathrm{H}_{2} \mathrm{PO}_{4}^{-}-\mathrm{P}, \mathrm{K}^{+}, \mathrm{Ca}^{2+} \text { and } \mathrm{Mg}^{2-} \\
D D_{\mathrm{v}} & =\left(\frac{T S-P t}{P t}\right)_{\mathrm{SO}_{+}} \times P t_{4} \\
y & =\mathrm{NH}_{4}^{+}-\mathrm{N} \text { and } \mathrm{NO}_{3}^{-}-\mathrm{N}
\end{aligned}
$$

Once all the $D D$ values were obtained, canopy interactions were calculated using Eq. (2). A positive $\mathrm{Ci}$ value was considered as canopy leaching and a negative value as direct uptake from the canopy. This indicated the net result of the dominant processes occurring in the canopy. Thus, the rate of uptake $\left(C_{\text {up }}\right)$ from total deposition and the rate of leaching $\left(C_{\mathrm{lc}}\right)$ by $T S$ solutions were calculated as follows

$$
\begin{gathered}
C_{\mathrm{up}}(\%)=-\left(\frac{-C i}{T D}\right) \times 100 \text { and } \\
C_{\mathrm{tc}}(\%)=\left(\frac{C i}{T S}\right) \times 100
\end{gathered}
$$

\subsection{Nutrient budgets}

Nutrient budgets were established for the major cations and anions; two soil depths were successively considered as the output reference level: 60 $\mathrm{cm}$ depth for all stands and $120 \mathrm{~cm}$ depth for the 40 and 60 -year-old stands. The terms of these budgets were as follows

$$
\text { Input }=P t+D D+(\text { weathering })
$$

Because weathering could not be estimated reliably, it was not taken into account in the present input calculation.

Output $=$ Biomass immobilisation + leaching out of

the soil (P-60 or P-120)

Biomass immobilisation (roots not included) represented the mean current immobilisation (MCI) 

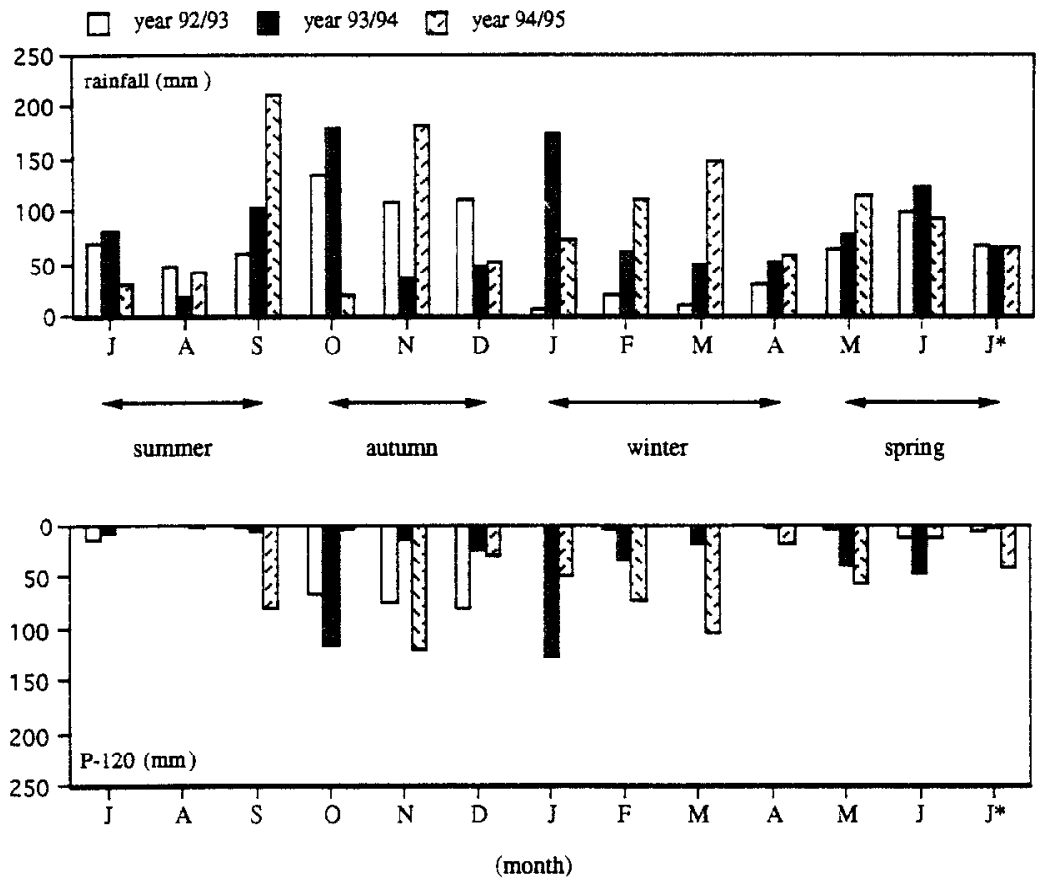

Fig. 3. Annual and seasonal variations of water input-output fluxes in the 40 -year-old stand. As sampling was done every 4 weeks, there are some months where sampling occurred twice.

Table 2

Annual water fluxes (mm) estimated by the water balance model (Villette, 1994)

\begin{tabular}{|c|c|c|c|c|c|c|c|c|c|c|c|c|}
\hline & \multirow[t]{2}{*}{$P t$} & \multirow[t]{2}{*}{$T$} & \multirow[t]{2}{*}{$S$} & \multirow[t]{2}{*}{ In } & \multirow[t]{2}{*}{ PET } & \multirow[t]{2}{*}{$E T$} & \multirow[t]{2}{*}{$T R$} & \multirow[t]{2}{*}{$E T_{\mathrm{u}}$} & \multicolumn{4}{|c|}{ Drainage $^{a}$} \\
\hline & & & & & & & & & P-15 & P-30 & P-60 & P-120 \\
\hline \multicolumn{13}{|c|}{20 -year-old stand } \\
\hline $1992 / 1993$ & 821 & 604 & 19 & 198 & 569 & 542 & 331 & 12 & 529 & 455 & 350 & 290 \\
\hline $1993 / 1994$ & 1060 & 778 & 24 & 257 & 601 & 614 & 344 & 13 & 702 & 621 & 511 & 449 \\
\hline $1994 / 1995$ & 1193 & 923 & 28 & 242 & 671 & 633 & 377 & 13 & 850 & 769 & 654 & 581 \\
\hline Year average & 1025 & 768 & 24 & 233 & 614 & 596 & 351 & 13 & 694 & 615 & 505 & 440 \\
\hline \multicolumn{13}{|c|}{ 40-year-old stand } \\
\hline $1992 / 1993$ & 821 & 604 & 19 & 198 & 569 & 567 & 331 & 38 & 459 & 382 & 308 & 265 \\
\hline $1993 / 1994$ & 1060 & 778 & 24 & 257 & 601 & 631 & 336 & 37 & 635 & 550 & 476 & 435 \\
\hline $1994 / 1995$ & 1193 & 923 & 28 & 242 & 671 & 618 & 339 & 37 & 798 & 718 & 635 & 595 \\
\hline Year average & 1025 & 768 & 24 & 233 & 614 & 605 & 335 & 37 & 631 & 550 & 473 & 432 \\
\hline \multicolumn{13}{|c|}{ 60-year-old stand } \\
\hline $1992 / 1993$ & 821 & 604 & 19 & 198 & 569 & 591 & 331 & 62 & 453 & 360 & 265 & 242 \\
\hline $1993 / 1994$ & 1060 & 778 & 24 & 257 & 601 & 654 & 337 & 60 & 628 & 528 & 435 & 413 \\
\hline $1994 / 1995$ & 1193 & 923 & 28 & 242 & 671 & 641 & 340 & 58 & 787 & 694 & 598 & 572 \\
\hline Year average & 1025 & 768 & 24 & 233 & 614 & 629 & 336 & 60 & 622 & 527 & 433 & 409 \\
\hline \multicolumn{13}{|c|}{ Annual average for all stands } \\
\hline & 1025 & 768 & 24 & 233 & 614 & 610 & 341 & 37 & 649 & 564 & 470 & 427 \\
\hline
\end{tabular}

${ }^{a} \mathrm{P}-15, \mathrm{P}-30, \mathrm{P}-60$ and P-120 represent drainage from $15,30,60$ and $120 \mathrm{~cm}$ depth, respectively.

$P t$, bulk precipitation; $T$, throughfall; $S$, stemflow; $I n$, interception; PET, Penman evapotranspiration; $E T$, estimated evapotranspiration; $T R$, transpiration; $E T_{\mathrm{u}}$, evapotranspiration of understorey. 
(a)
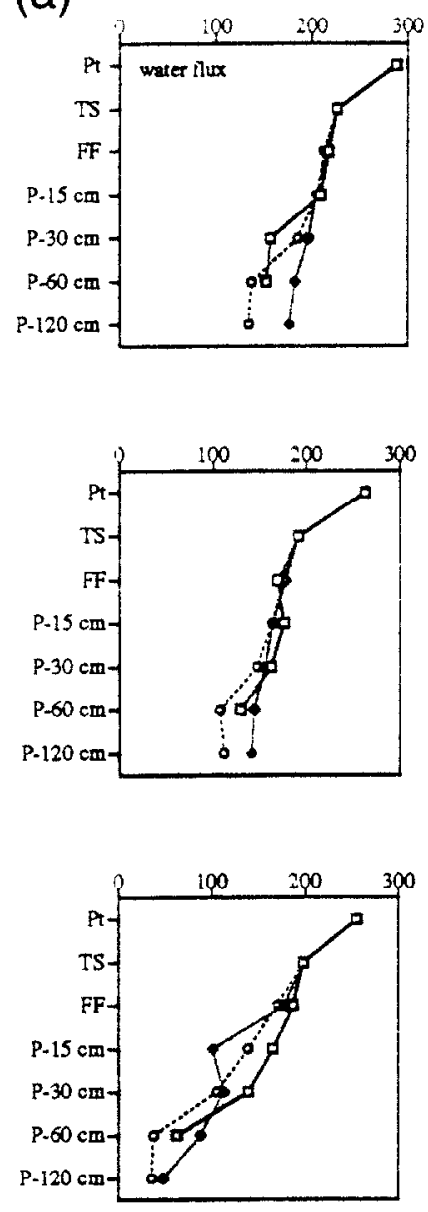

$\operatorname{Act} M x$
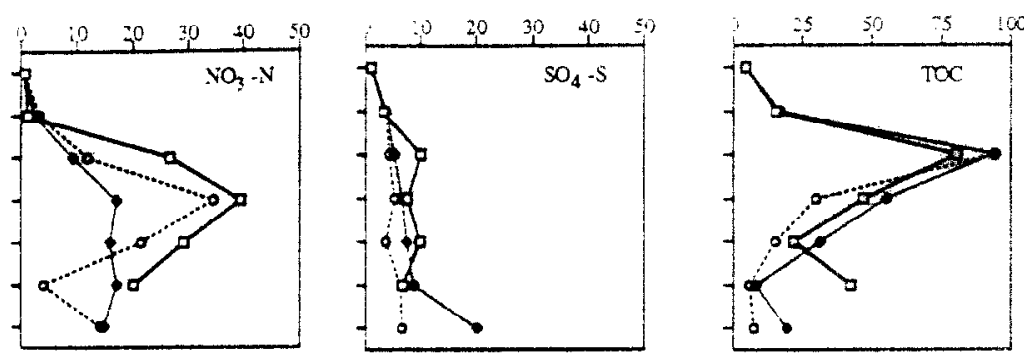

WINTER
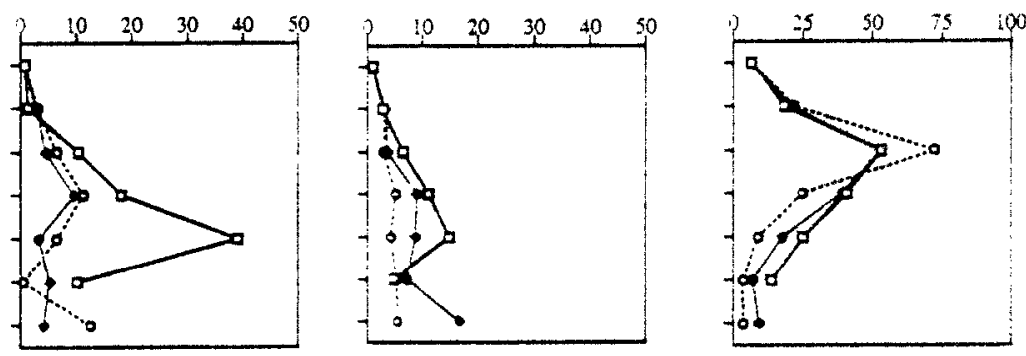

SPRING
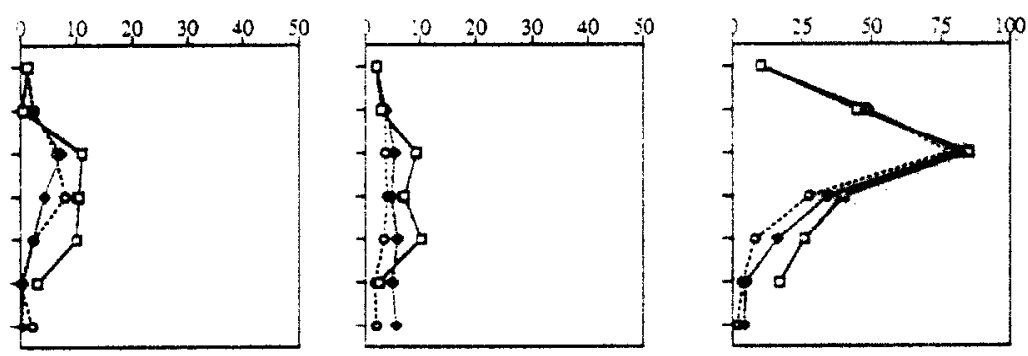

SUMMER
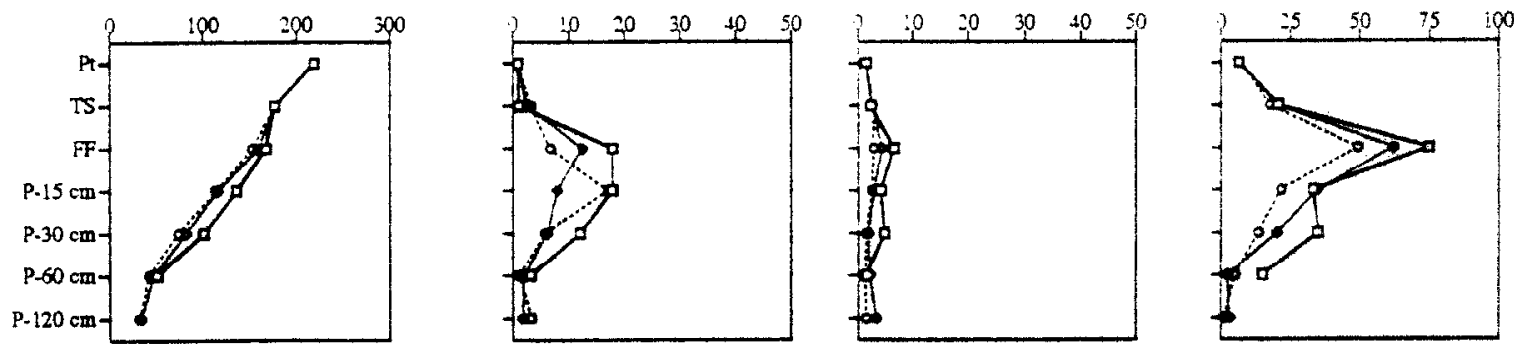

\section{$\rightarrow 20$ year-oidd $\rightarrow 40$ year-old $\cdots \rightarrow 60$ year-old}

Fig. 4. (a) Mean seasonal water (mm) and $\mathrm{NO}_{3}-\mathrm{N}_{1} \mathrm{SO}_{4}-\mathrm{S}$ and TOC fluxes ( $\mathrm{kg} \mathrm{ha}{ }^{-1}$ per season) in the compartments of the forest stands. (b) Mean seasonal $\mathrm{Ca}, \mathrm{Mg}, \mathrm{Al}$ and $\mathrm{K}$ fluxes ( $\mathrm{kg} \mathrm{ha}{ }^{-1}$ per season) in the compartments of the forest stands. (c) Mean seasonal Si, $\mathrm{Mn}, \mathrm{Na}$ and $\mathrm{Cl}$ fluxes ( $\mathrm{kg} \mathrm{ha}^{-1}$ per season) in the compartments of the forest stands. (d) Mean seasonal $\mathrm{P}, \mathrm{NH}_{4}-\mathrm{N}$ and $\mathrm{H}$ fluxes $\left(\mathrm{kg}\right.$ ha ${ }^{-1}$ per season) in the compartments of the forest stands. 
(b)
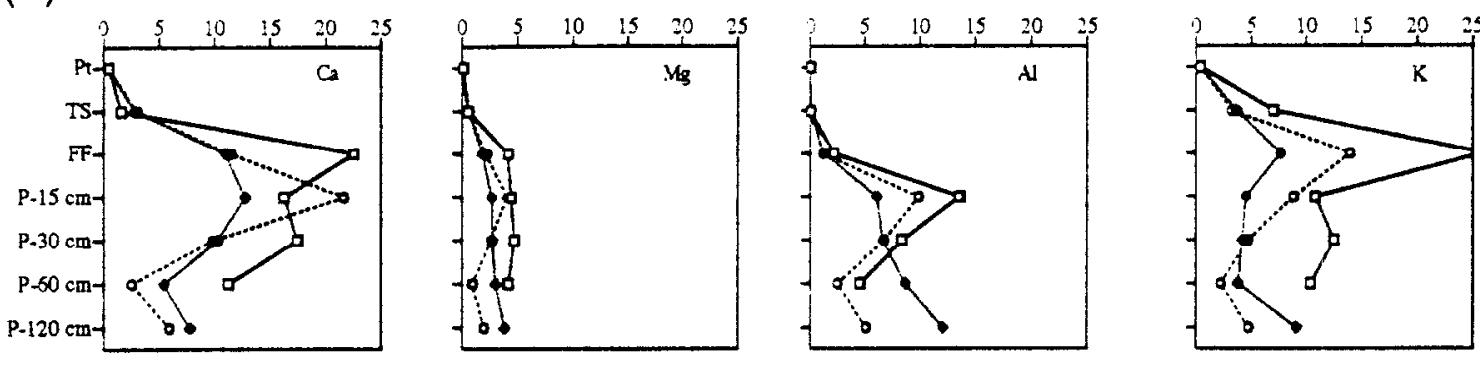

WINTER
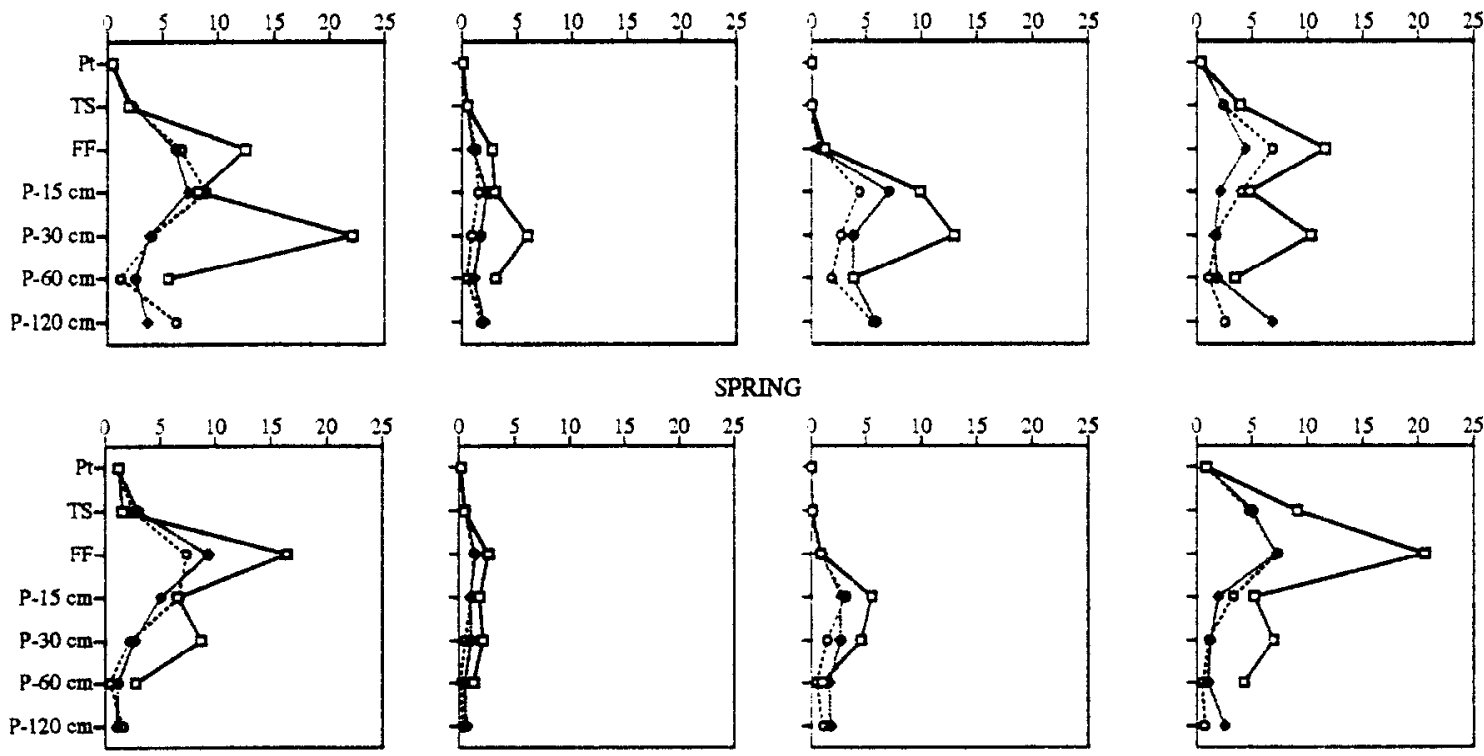

SUMMER
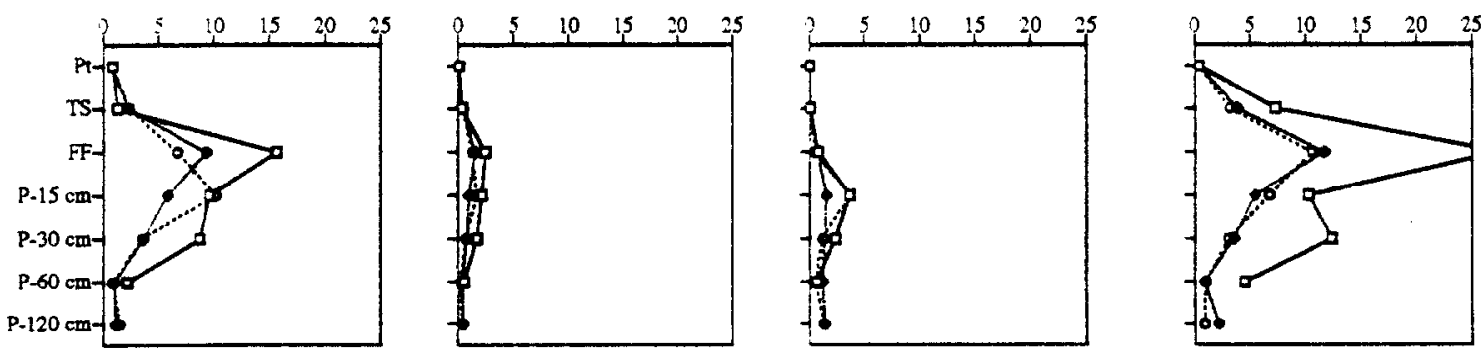

$\longrightarrow 20$ year-old $\longrightarrow 40$ year-old $\cdots \rightarrow-60$ year-old

Fig. 4 (continued). 
(c)
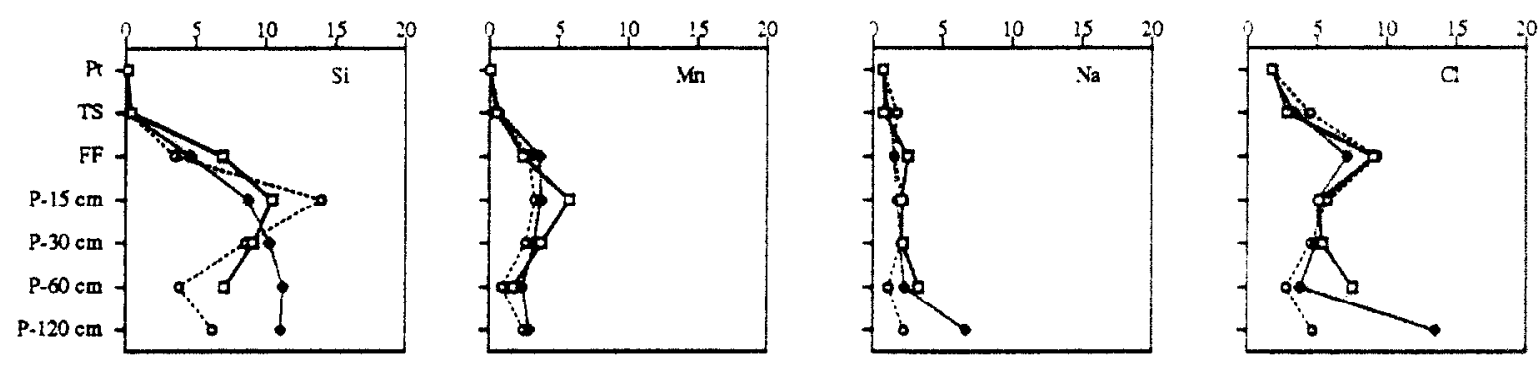

WINTER
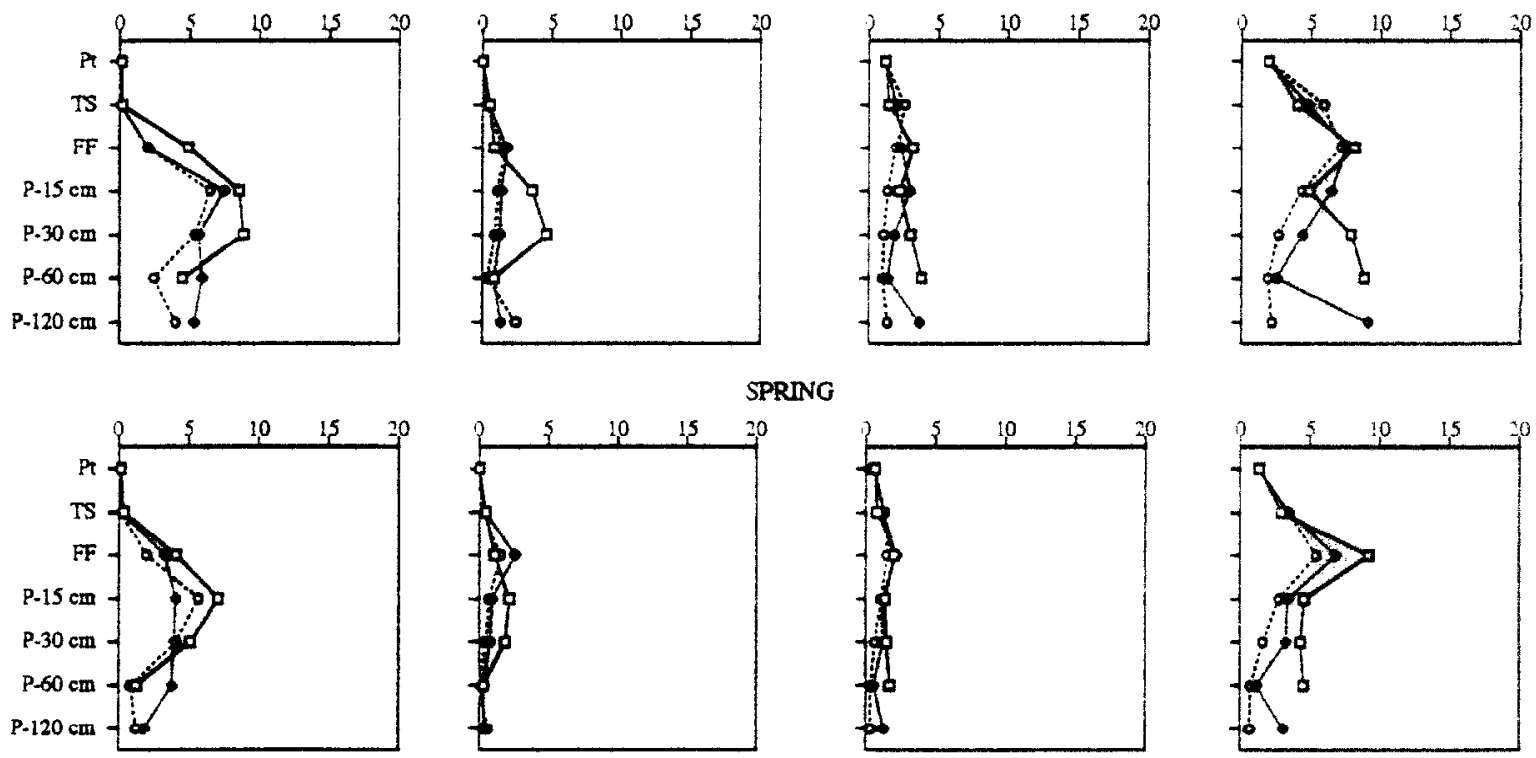

SUMMER
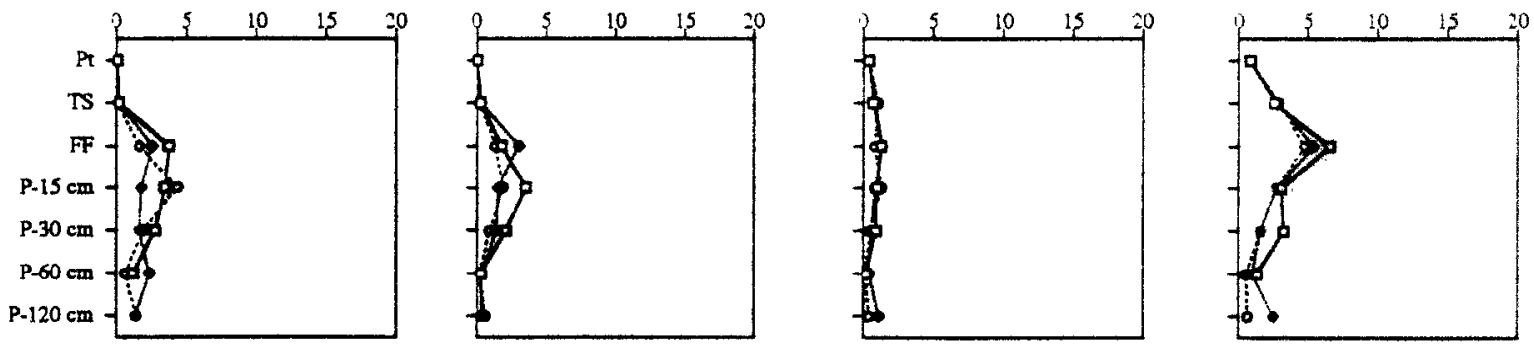

$\longrightarrow 20$ year-old $\longrightarrow 40$ year-old $\cdots-\infty-60$ year-old

Fig. 4 (continued). 
(d)

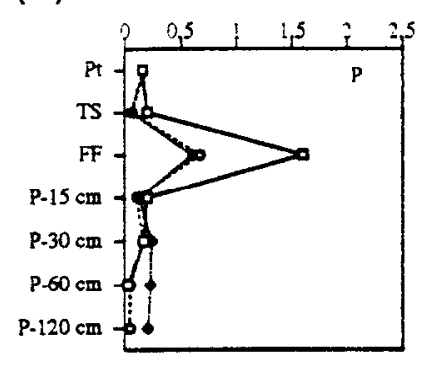

ALTTMN
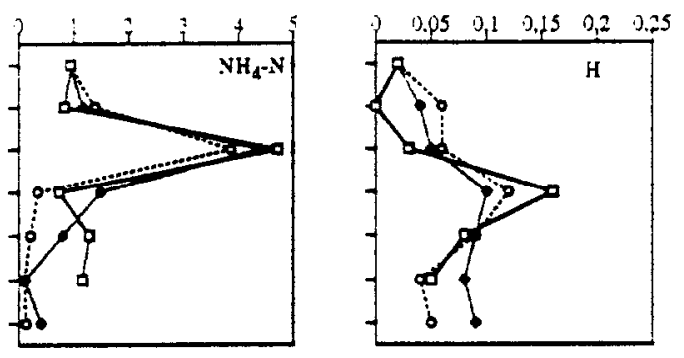

WINTER
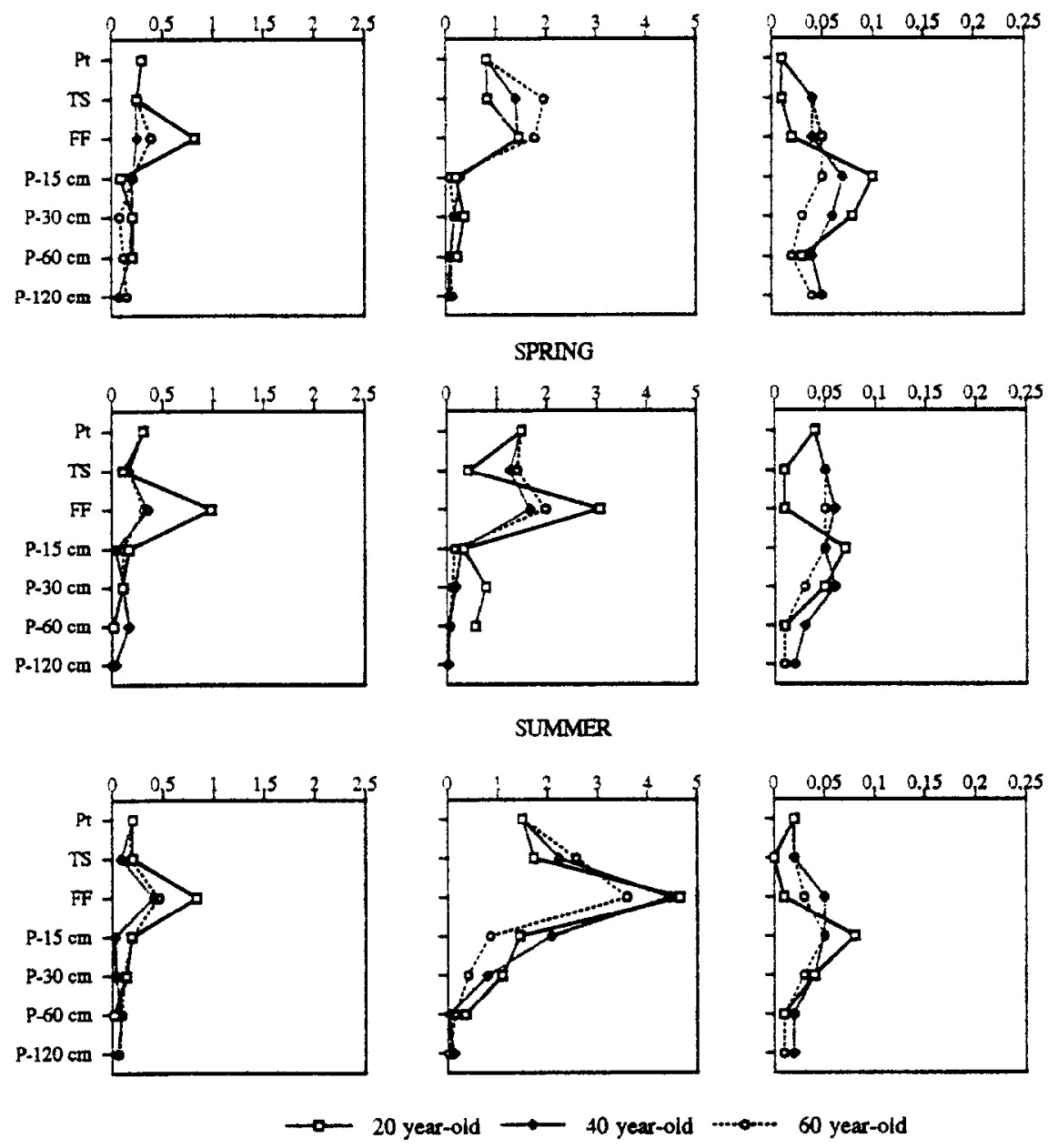

Fig. 4 (continued). 
which was calculated from the total nutrient content (Tnc) estimated for each stand (Ranger et al., 1995)

$\operatorname{MCI}(20$-year-old stand $)=\frac{(\text { Tnc } 20)}{20}$

$\operatorname{MCI}(40-$ year-old stand $)=\frac{(\operatorname{Tnc} 40-\operatorname{Tnc} 20)}{20}$

$\operatorname{MCI}(60$-year-old stand $)=\frac{(\text { Tnc 60-Tnc } 40)}{20}$

For the 40- and 60-year-old stands, the nutrient amount exported by thinning was included in the calculation of MCI. This amount was evaluated by applying the mean nutrient concentrations observed in the samples to the biomass exported by thinnings (data given by the Forest Manlagement Service).

Budgets for rotations lasting of 20,40 or 60 years were calculated as follows:

Reference level at $60 \mathrm{~cm}$ depth

20-year-old stand: average annual budget (20year-old stand) $\times 20(\mathrm{~A})$

40-year-old stand: average annual budget (40year-old stand) $\times 20+A(B)$

60-year-old stand: average annual budget (60year-old stand) $\times 20+B$

Reference level at $120 \mathrm{~cm}$ depth

40-year-old stand: average annual budget (40year-old stand) $\times 40(\mathrm{C})$

60 -year-old stand: average annual budget $(60$ year-old stand) $\times 20+C$

\section{Results}

\subsection{Water flux}

Precipitation averaged $1025 \mathrm{~mm}$ per year. The first year sampled (1992/1993) was drier than the others with a total rainfall of $821 \mathrm{~mm}$ and a particularly dry winter period. Mean seasonal rainfall was lowest in summer, when the water flux at the bottom of the soil was very low (Fig. 3).

Canopy interception, throughfall and stemflow amounted to $23 \%, 75 \%$ and $2 \%$ of mean incident rainfall, respectively. The mean annual loss of water by $E T$ and $T R$ was $610 \mathrm{~mm}$ and $341 \mathrm{~mm}$, respectively, i.e. $60 \%$ and $33 \%$ of the incident precipitation (Table 2).
Water fluxes decreased from $P t$ to $\mathrm{P}-120$ and this decrease was more accentuated during spring and summer (Fig. 4(a)).

Net annual water loss at the soil bottom averaged $427 \mathrm{~mm}$ but a strong variability (range $=250-600$ $\mathrm{mm}$ ) related to rainfall input was observed. Stand variability was limited, less than $5 \%$ of the general mean.

\subsection{Nutrient flux}

Nutrient fluxes showed the following general trend: (i) they were low in the first two compartments ( $P t$ and $T S$ ), (ii) increased in the upper soil layers (from FF to P-30) and then (iii) decreased with soil depth (Fig. 4(a)Fig. 4(b)Fig. 4(c)Fig. 4(d)).

Mean annual fluxes of the three stands are presented in Table 3 . Yearly rainfall input to the ecosystem per hectare was $27.4 \mathrm{~kg}$ TOC, $5.9 \mathrm{~kg} \mathrm{Cl}^{-}, 5.5$ $\mathrm{kg} \mathrm{SO}_{4}^{2-}-\mathrm{S}, 4.8 \mathrm{~kg} \mathrm{NO}_{3}^{-}-\mathrm{N}, 3.6 \mathrm{~kg} \mathrm{NH}_{4}^{+}-\mathrm{N}, 3.1 \mathrm{~kg}$ $\mathrm{Ca}^{2+}, 3.0 \mathrm{~kg} \mathrm{Na}^{+}, 2.0 \mathrm{~kg} \mathrm{~K}^{+}, 1.0 \mathrm{~kg} \mathrm{H}_{2} \mathrm{PO}_{4}^{-}-\mathrm{P}$ and less than $1.0 \mathrm{~kg}$ for $\mathrm{Si}, \mathrm{Mg}^{2+}, \mathrm{Mn}^{2+}, \mathrm{H}^{+}, \mathrm{Al}^{3+}$, and $\mathrm{Fe}^{2+}$.

$T S$ solutions were enriched in some elements and impoverished in others as a consequence of canopy interactions. The partitioning of atmospheric input was used to estimate dry deposition, canopy leaching and direct uptake of nutrients by the canopy (Table 4). Mean total deposition (TD) was estimated at 12.5 $\mathrm{kg} \mathrm{S}, 10.8 \mathrm{~kg} \mathrm{NH}_{4}^{+}-\mathrm{N}, 8.2 \mathrm{~kg} \mathrm{NO}_{3}^{-} \mathrm{N}, 5.7 \mathrm{~kg} \mathrm{Ca}^{2+}$. $5.3 \mathrm{~kg} \mathrm{Na}^{+}, 3.5 \mathrm{~kg} \mathrm{~K}^{+}, 1.6 \mathrm{~kg} \mathrm{H}_{2} \mathrm{PO}_{4}^{-}-\mathrm{P}$ and $1.0 \mathrm{~kg}$ $\mathrm{Mg}^{2+}$ ha ${ }^{-1}$ year ${ }^{-1}$. Some $58 \%$ of $\mathrm{H}_{2} \mathrm{PO}_{4}^{-}-\mathrm{P}$ and $48 \%$ of $\mathrm{NH}_{4}^{+}-\mathrm{N}$ were in average taken up from the total deposition by the canopy. $\mathrm{K}-, \mathrm{Ca}-$ and $\mathrm{Mg}-$ leaching were respectively estimated at $78 \%$. 36\% and $52 \%$ of TS. Thus, fluxes reaching the soil surface (TS) were on average $103.0 \mathrm{~kg}$ TOC, $18.6 \mathrm{~kg}$ $\mathrm{K}^{+}, 14.6 \mathrm{~kg} \mathrm{Cl}^{-}, 12.5 \mathrm{~kg} \mathrm{SO}_{4}^{2-}-\mathrm{S}, 9.1 \mathrm{~kg} \mathrm{Ca}^{2+}, 8.6$ $\mathrm{kg} \mathrm{NO}_{3}^{-}-\mathrm{N}, 5.7 \mathrm{~kg} \mathrm{NH} \mathrm{NH}_{4}^{+} \mathrm{N}, 5.3 \mathrm{~kg} \mathrm{Na}^{+} .2 .1 \mathrm{~kg}$ $\mathrm{Mg}^{2+}$ and less than $2.0 \mathrm{~kg}$ for $\mathrm{Mn}^{2+}, \mathrm{Si}, \mathrm{H}_{2} \mathrm{PO}_{4}^{-}-\mathrm{P}$. $\mathrm{Fe}^{2+}, \mathrm{Al}^{3+}$ and $\mathrm{H}^{+}$ha ${ }^{-1}$ year ${ }^{-1}$ (Table 3).

The downward fluxes (FF) of all elements significantly increased, the highest nutrient fluxes were those of $\mathrm{K}^{+} \cdot \mathrm{Ca}^{2+}$, and $\mathrm{NO}_{3}^{-}-\mathrm{N}$, which averaged, respectively, $51.8,45.0$ and $43.6 \mathrm{~kg} \mathrm{ha}^{-1}$ year $^{-1}$.

Most of the fluxes then decreased with depth, but large amounts of nutrients flowed out of the deepest soil layer where mean fluxes amounted to $30.7 \mathrm{~kg}$ 
$\mathrm{SO}_{4}^{2-}-\mathrm{S}, 26.6 \mathrm{~kg} \mathrm{NO}_{3}^{-}-\mathrm{N}, 14.8 \mathrm{~kg} \mathrm{~K}^{+}$and $14.5 \mathrm{~kg}$ $\mathrm{Ca}^{2+} \mathrm{ha}^{-1}$ year $^{-1}$ (Table 3 ).

\subsection{Seasonal and stand age variations}

Seasonal patterns according to stand age are presented for some elements on Fig. 4(a)Fig. 4(b)Fig. 4(c)Fig. 4(d). Most elements reached their highest values in autumn and winter. During these scasons, the decreasing trend with depth did not occur; several elements showed higher fluxes at P-120 than in the upper layers. Elements like $\mathrm{NO}_{3}^{-}-\mathrm{N}, \mathrm{K}^{+}, \mathrm{Ca}^{2+}$ and $\mathrm{Mn}^{2+}$ also showed large fluxes in summer. TOC, at the $F F$ level, was elevated throughout the year.

Fluxes of most elements were highest in the 20-year-old stand, irrespective of season and compartment except for $\mathrm{NO}_{3}^{-}-\mathrm{N}, \mathrm{Ca}^{2+}, \mathrm{Na}^{+}$and $\mathrm{Cl}^{-}$in $P t$ and $T S$.

Comparing fluxes was more complicated in the other two stands. In spring and summer, fluxes at all levels were low and generally less variable between stands than during the other seasons. In autumn and winter, $P t$ and $T S$ did not differ between the 40- and

Table 3

Mean annual fluxes in the stands and average fluxes for all stands (values are in $\mathrm{kg} \mathrm{ha}^{-1}$ year $^{-1}$, except for water flux which is in mm)

\begin{tabular}{|c|c|c|c|c|c|c|c|c|c|c|c|c|c|c|c|c|}
\hline Compartment & Water flux & $\mathrm{NH}_{4}-\mathrm{N}$ & $\mathrm{NO}_{3}-\mathrm{N}$ & $\mathrm{SO}_{4}-\mathrm{S}$ & $\mathrm{H}_{2} \mathrm{PO}_{4}-\mathrm{P}$ & $\mathrm{K}$ & $\mathrm{Ca}$ & $\mathrm{Mg}$ & $\mathrm{Na}$ & $\mathrm{Mn}$ & $\mathbf{H}$ & Al & $\mathrm{Fe}$ & $\mathrm{Si}$ & $\mathrm{Cl}$ & TOC \\
\hline \multicolumn{17}{|c|}{ 20-year-old stand } \\
\hline$P t$ & 1025 & 4.8 & 3.6 & 5.5 & 1.0 & 2.0 & 3.1 & 0.6 & 3.0 & 0.2 & 0.1 & 0.1 & 0.4 & 0.6 & 5.9 & 27.4 \\
\hline$T S$ & 792 & 3.8 & 4.0 & 11.2 & 0.8 & 27.4 & 6.5 & 2.0 & 3.7 & 1.9 & 0.0 & 0.2 & 0.5 & 1.1 & 12.4 & 98.7 \\
\hline$F F$ & 741 & 13.9 & 66.0 & 32.4 & 4.2 & 85.6 & 67.1 & 12.1 & 9.1 & 6.3 & 0.1 & 5.2 & 1.4 & 19.6 & 33.0 & 293.5 \\
\hline P-15 & 686 & 2.7 & 85.8 & 30.0 & 0.7 & 31.1 & 40.7 & 11.5 & 6.7 & 15.0 & 0.4 & 32.7 & 1.5 & 29.6 & 17.7 & 160.8 \\
\hline P-30 & 559 & 3.5 & 90.3 & 39.7 & 0.6 & 42.2 & 56.9 & 14.5 & 7.6 & 12.3 & 0.3 & 28.3 & 0.6 & 25.8 & 20.9 & 107.5 \\
\hline P-60 & 395 & 2.3 & 36.6 & 15.5 & 0.3 & 22.7 & 21.7 & 9.1 & 9.1 & 3.2 & 0.1 & 10.1 & 0.4 & 14.0 & 22.2 & 87.8 \\
\hline \multicolumn{17}{|c|}{ 40-year-old stand } \\
\hline$P r$ & 1025 & 4.8 & 3.6 & 5.5 & 1.0 & 2.0 & 3.1 & 0.6 & 3.0 & 0.2 & 0.1 & 0.1 & 0.4 & 0.6 & 5.9 & 27.4 \\
\hline$T S$ & 792 & 6.0 & 10.1 & 13.5 & 0.6 & 15.0 & 10.7 & 2.2 & 5.3 & 2.1 & 0.2 & 0.4 & 0.6 & 0.6 & 14.6 & 106.0 \\
\hline$F F$ & 730 & 12.0 & 33.3 & 18.8 & 1.6 & 31.0 & 35.8 & 5.9 & 7.4 & 11.1 & 0.2 & 3.6 & 2.1 & 12.6 & 27.0 & 290.7 \\
\hline P-15 & 586 & 4.1 & 38.7 & 23.5 & 0.4 & 14.0 & 30.9 & 7.0 & 6.7 & 7.6 & 0.3 & 17.5 & 1.0 & 22.0 & 17.7 & 163.0 \\
\hline $\mathrm{P}-30$ & 547 & 2.0 & 27.6 & 23.9 & 0.6 & 10.6 & 20.4 & 6.4 & 5.6 & 6.7 & 0.2 & 14.6 & 0.6 & 21.5 & 14.1 & 85.0 \\
\hline P-60 & 462 & 0.3 & 24.9 & 23.1 & 0.7 & 7.7 & 10.2 & 5.1 & 4.7 & 4.1 & 0.2 & 15.4 & 0.3 & 23.3 & 8.5 & 22.5 \\
\hline P-120 & 399 & 0.6 & 21.1 & 45.6 & 0.4 & 20.6 & 13.6 & 7.0 & 12.7 & 5.0 & 0.2 & 21.2 & 0.3 & 19.5 & 28.2 & 35.8 \\
\hline \multicolumn{17}{|c|}{60 -year-old stand } \\
\hline$P t$ & 1025 & 4.8 & 3.6 & 5.5 & 1.0 & 2.0 & 3.1 & 0.6 & 3.0 & 0.2 & 0.1 & 0.1 & 0.4 & 0.6 & 5.9 & 27.4 \\
\hline$T S$ & 792 & 7.3 & 11.8 & 12.7 & 0.7 & 13.4 & 10.1 & 2.2 & 6.8 & 1.5 & 0.2 & 0.5 & 0.6 & 0.6 & 16.8 & 104.2 \\
\hline$F F$ & 709 & 11.2 & 31.5 & 13.7 & 1.8 & 38.8 & 32.2 & 6.1 & 5.8 & 7.2 & 0.2 & 3.3 & 1.8 & 9.0 & 26.7 & 294.0 \\
\hline P-15 & 620 & 1.5 & 70.8 & 16.9 & 0.6 & 23.0 & 47.4 & 8.4 & 5.9 & 7.0 & 0.3 & 21.1 & 0.6 & 30.4 & 15.5 & 103.4 \\
\hline P-30 & 511 & 0.9 & 36.0 & 12.7 & 0.5 & 10.5 & 19.5 & 4.8 & 4.2 & 5.0 & 0.2 & 12.0 & 0.4 & 19.9 & 10.4 & 45.2 \\
\hline$P-60$ & 324 & 0.4 & 5.9 & 14.7 & 0.3 & 4.9 & 5.1 & 1.8 & 2.7 & 1.7 & 0.1 & 5.4 & 0.2 & 7.8 & 6.0 & 17.7 \\
\hline$P-120$ & 312 & 0.3 & 32.2 & 15.7 & 0.3 & 9.0 & 15.3 & 4.6 & 4.3 & 6.2 & 0.1 & 13.1 & 0.2 & 12.8 & 8.2 & 14.1 \\
\hline \multicolumn{17}{|c|}{ Acerage for all stands } \\
\hline$P t$ & 1025 & 4.8 & 3.6 & 5.5 & 1.0 & 2.0 & 3.1 & 0.6 & 3.0 & 0.2 & 0.1 & 0.1 & 0.4 & 0.6 & 5.9 & 27.4 \\
\hline$T S$ & 792 & 5.7 & 8.6 & 12.5 & 0.7 & 18.6 & 9.1 & 2.1 & 5.3 & 1.8 & 0.1 & 0.4 & 0.6 & 0.8 & 14.6 & 103.0 \\
\hline$F F$ & 727 & 12.4 & 43.6 & 21.6 & 2.6 & 51.8 & 45.0 & 8.0 & 7.4 & 8.2 & 0.2 & 4.0 & 1.8 & 13.7 & 28.9 & 292.7 \\
\hline$P-15$ & 631 & 2.8 & 65.1 & 23.5 & 0.6 & 22.7 & 39.7 & 9.0 & 6.4 & 9.9 & 0.3 & 23.7 & 1.1 & 27.3 & 17.0 & 142.4 \\
\hline P-30 & 539 & 2.1 & 51.3 & 25.4 & 0.6 & 21.1 & 32.2 & 8.6 & 5.8 & 8.0 & 0.2 & 18.3 & 0.5 & 22.4 & 15.1 & 79.2 \\
\hline P-60 & 394 & 1.0 & 22.5 & 17.8 & 0.4 & 11.8 & 12.4 & 5.4 & 5.5 & 3.0 & 0.1 & 10.3 & 0.3 & 15.0 & 12.2 & 42.7 \\
\hline $\mathrm{P}-120^{\mathrm{a}}$ & 356 & 0.5 & 26.6 & 30.7 & 0.3 & 14.8 & 14.5 & 5.8 & 8.5 & 5.6 & 0.1 & 17.2 & 0.2 & 16.2 & 18.2 & 24.9 \\
\hline
\end{tabular}

average for the 40- and 60-year-old stands.

Pt. bulk precipitation; TS, throughflow + stemflow; FF, forest floor; P-15, P-30, P-60 and P-120, lysimeters at $15,30,60$ and $120 \mathrm{~cm}$ depth. 


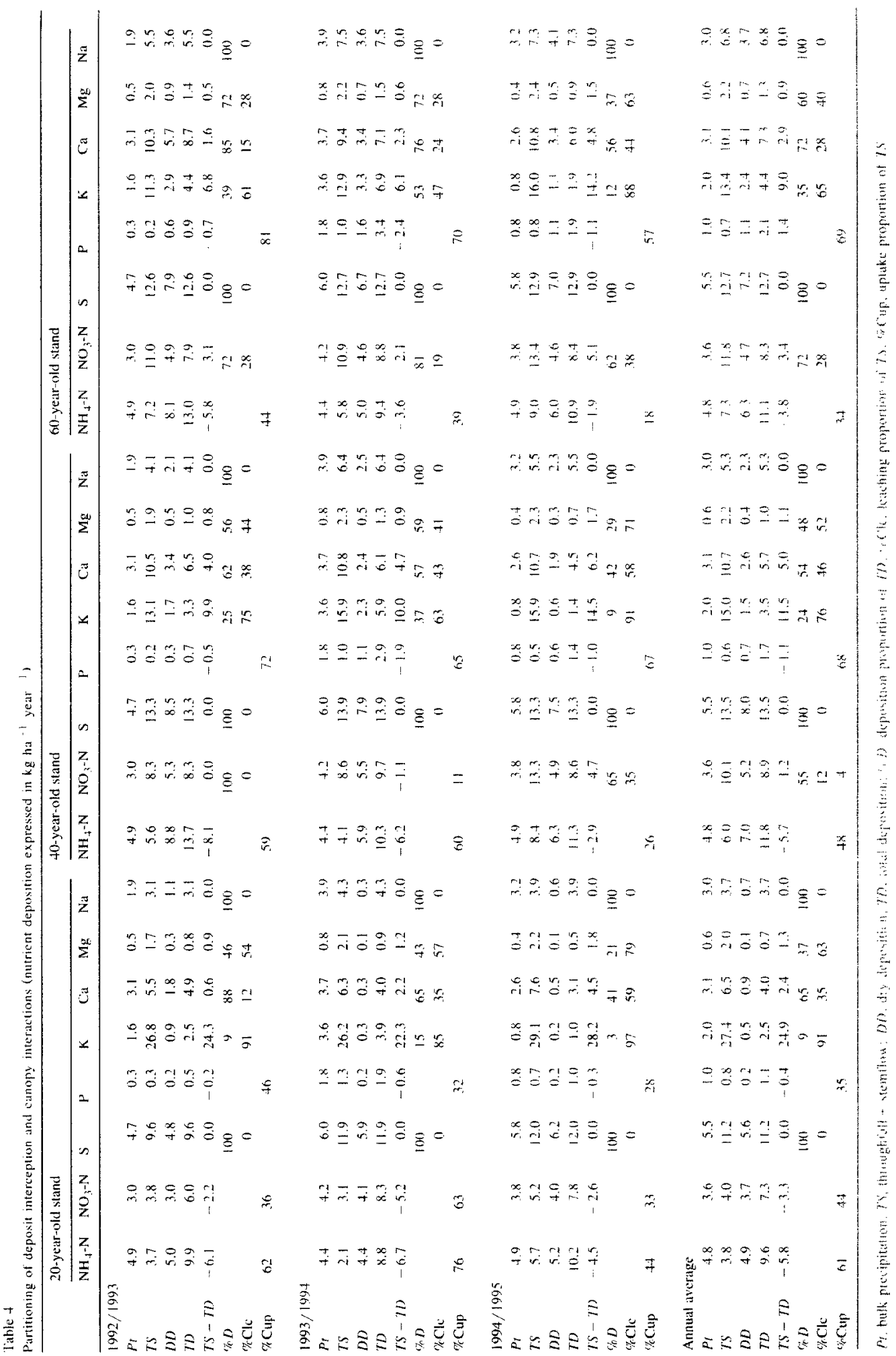




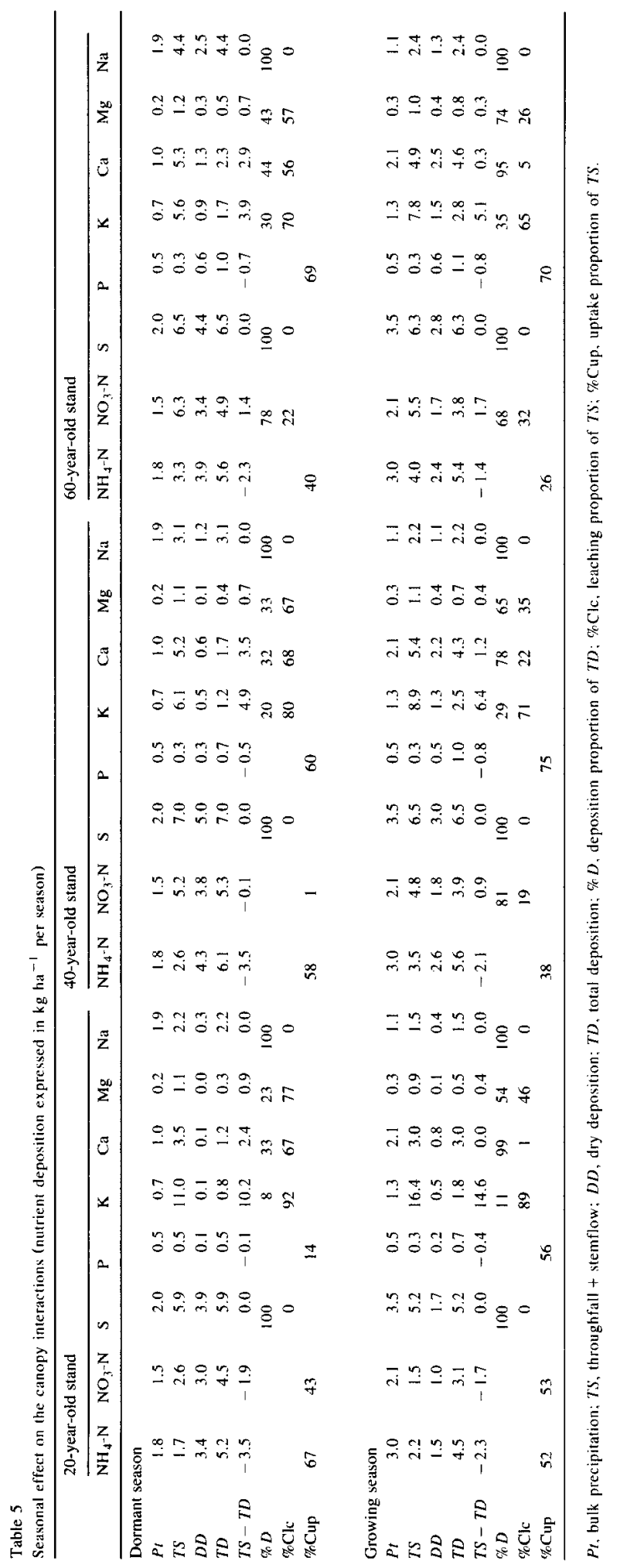




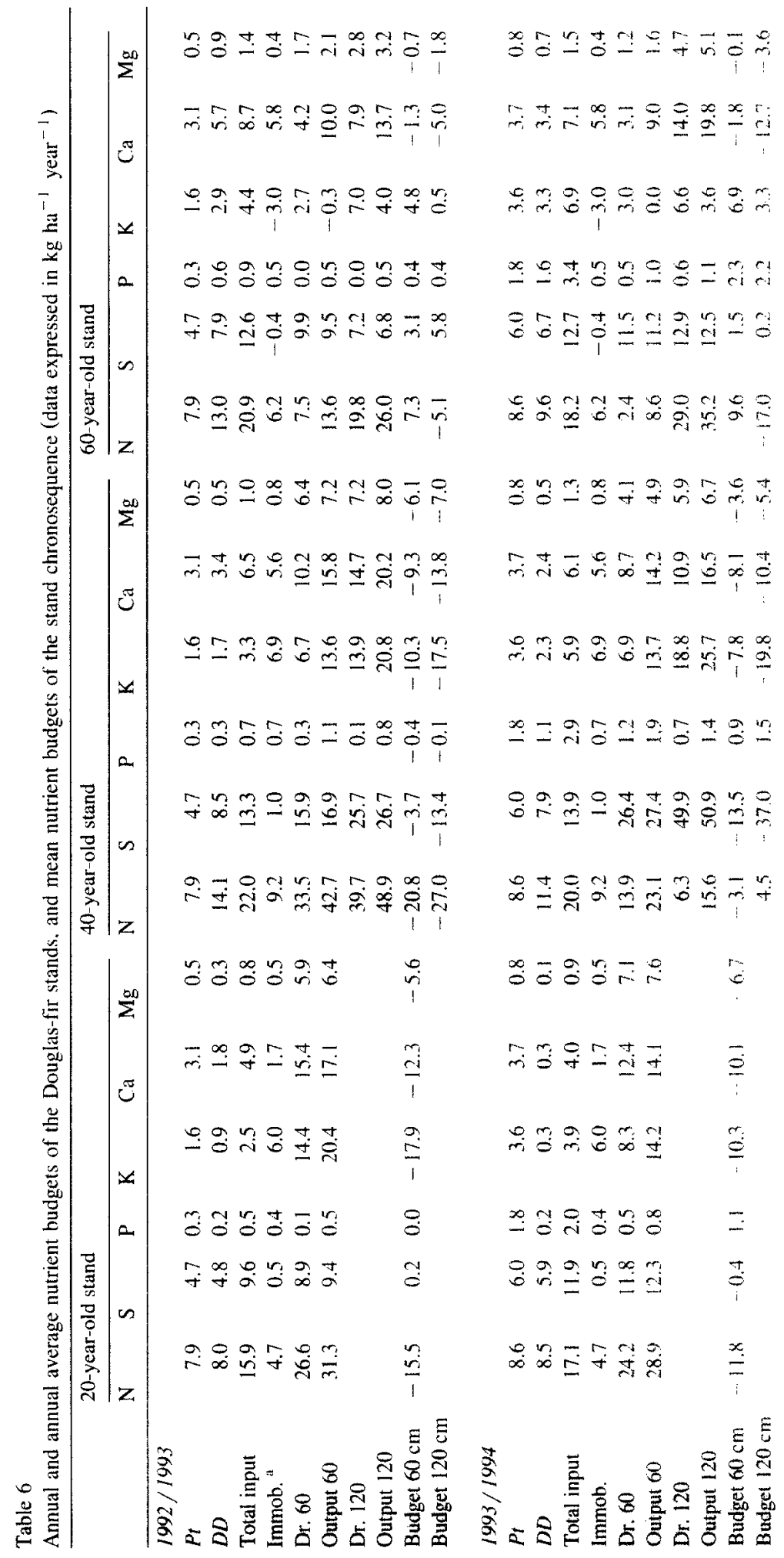




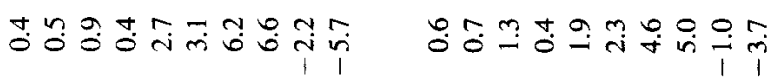

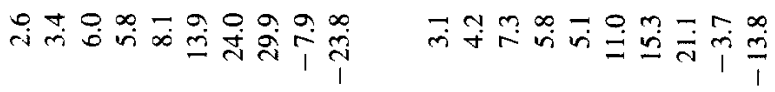

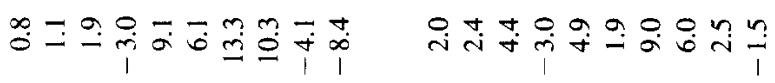

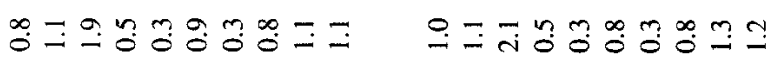

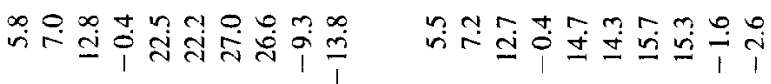

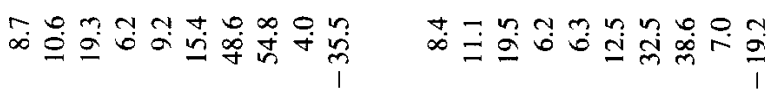

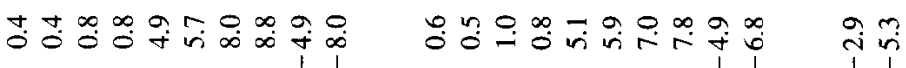

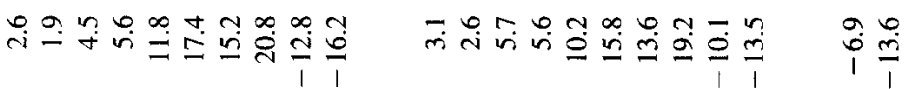

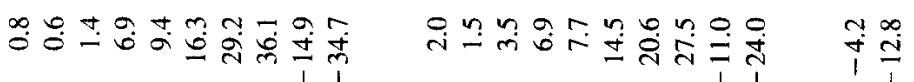

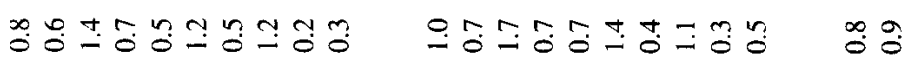

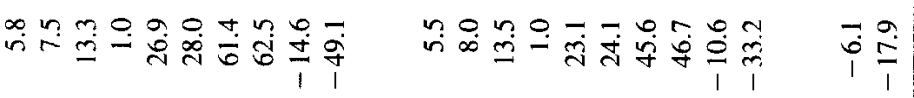

๙

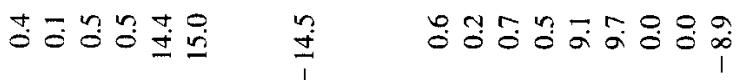

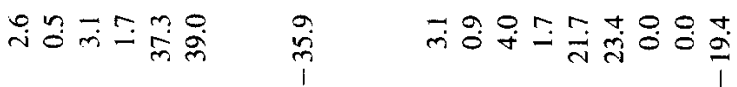

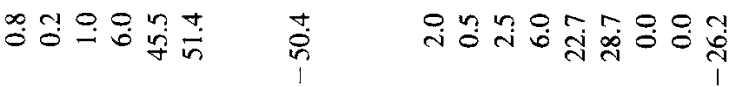

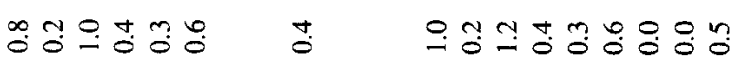

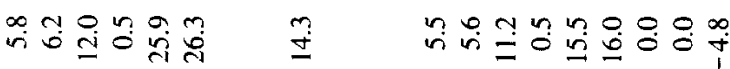

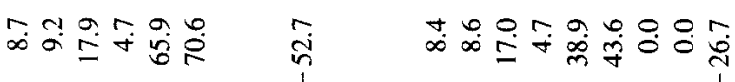

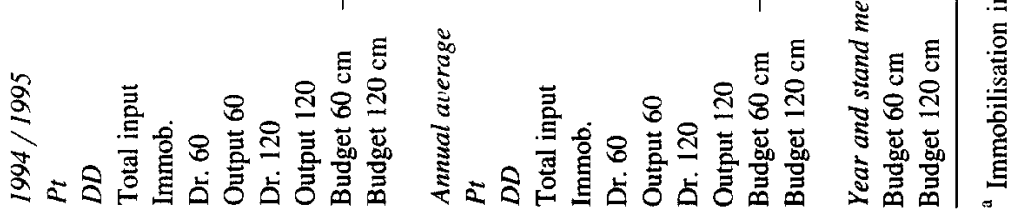




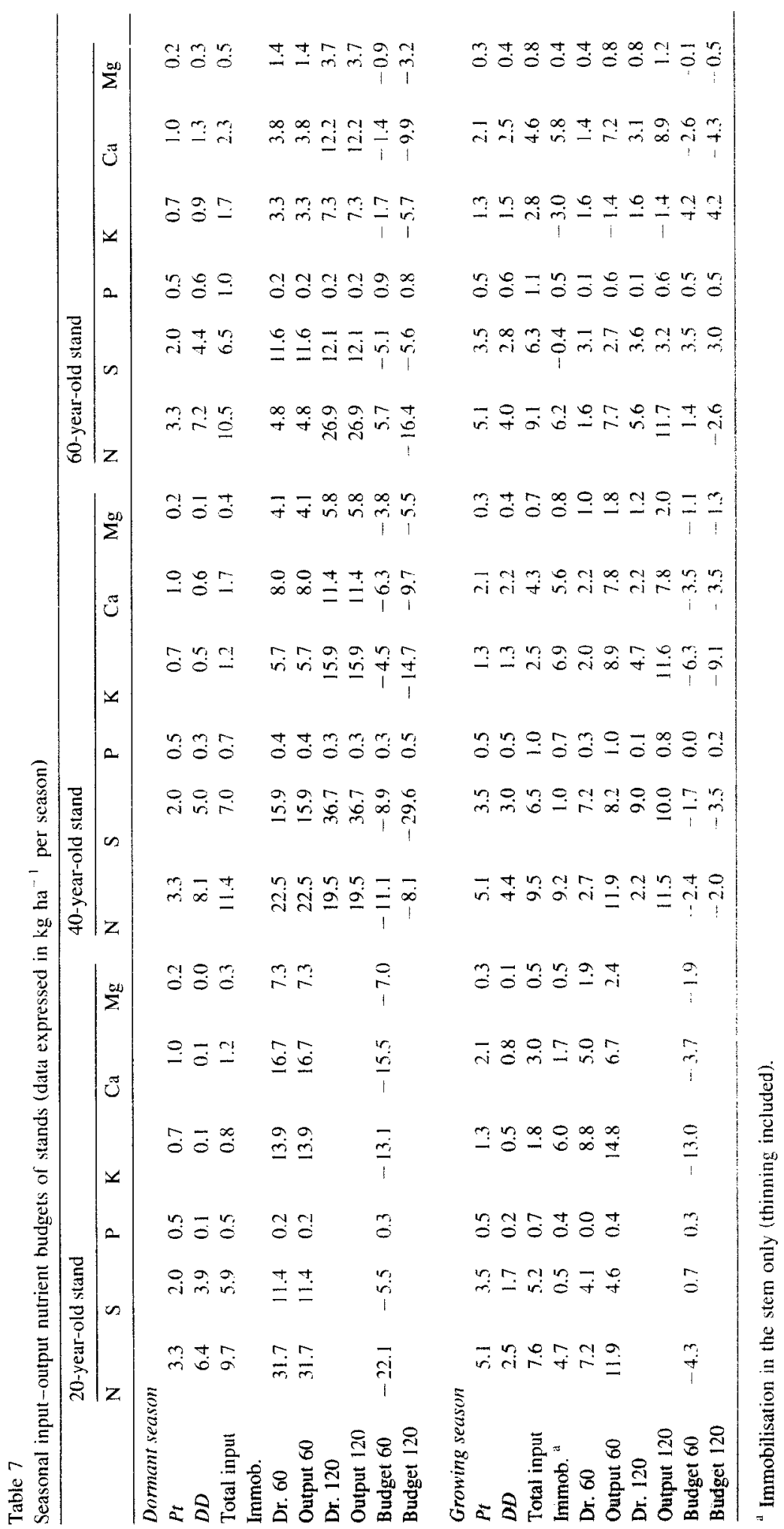




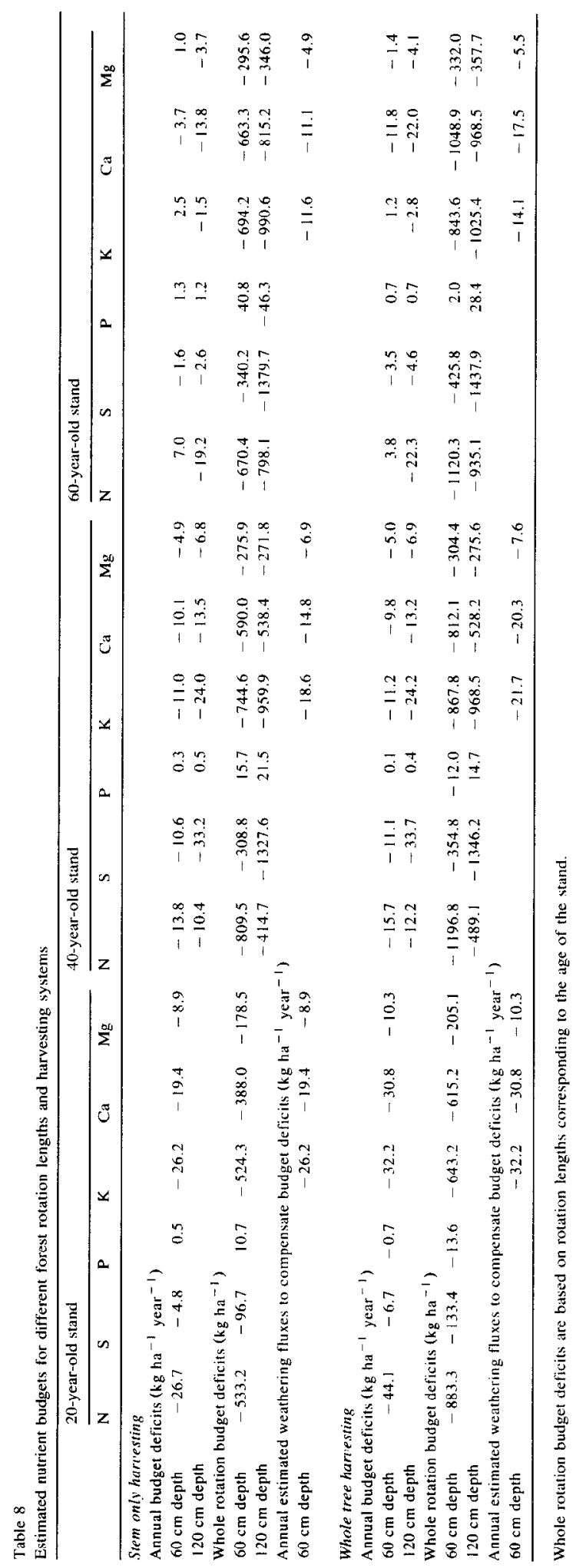


60-year-old stands. $\mathrm{SO}_{4}^{2-}-\mathrm{S}, \mathrm{TOC}, \mathrm{Cl}^{-}, \mathrm{Na}^{+}$, and $\mathrm{Mn}^{2+}$ fluxes tended to be highest in the 40-year-old stand for all soil layers. $\mathrm{NO}_{3}^{-}-\mathrm{N}, \mathrm{K}^{+}$and $\mathrm{Ca}^{2+}$ tended to be highest in the 60-year-old stand, and TOC and $\mathrm{Mn}^{2+}$ in the 40-year-old stand at $15 \mathrm{~cm}$ depth. Below this depth, $\mathrm{NO}_{3}^{-}-\mathrm{N}, \mathrm{K}^{+}, \mathrm{Ca}^{2+}$, TOC and $\mathrm{Mn}^{2+}$ tended to be the highest in the 40-year-old stand. $\mathrm{Al}^{3+}$ and $\mathrm{Mg}^{2+}$ were highest in the 40-yearold stand at all depths in winter and below $30 \mathrm{~cm}$ in autumn.

Canopy interactions were also strongly affected by stand age and seasonality (Tables 4 and 5). Uptake of $\mathrm{NH}_{4}^{+}-\mathrm{N}$ and $\mathrm{NO}_{3}^{-}-\mathrm{N}$ tended to be a little higher in the 20-year-old stand than in the older stands, and the reverse was true for $\mathrm{H}_{2} \mathrm{PO}_{4}^{-}-\mathrm{P}$. No $\mathrm{NO}_{3}^{-}-\mathrm{N}$ uptake was observed in the 60 -year-old stand and in the 40-year-old stand the uptake of nitrate was only observed during 1 year. Most of the $\mathrm{NH}_{4}^{+}-\mathrm{N}$. $\mathrm{NO}_{3}^{-}-\mathrm{N}$ and $\mathrm{H}_{2} \mathrm{PO}_{4}^{-}-\mathrm{P}$ uptake occurred in spring (Fig. 4). K- and $\mathrm{Mg}$-leaching were as follows: 20 year-old $>40$-year-old $>60$-year-old stand, but $\mathrm{Ca}$ leaching was highest in the 40 -year-old stand. Values of $\mathrm{Ca}$ - and $\mathrm{Mg}$-leaching were larger during the dormant season (autumn-winter) (Table 5). Seasonality of $\mathrm{K}^{+}$and TOC fluxes in $T S$ solutions was as follows: spring $>$ summer $\geq$ autumn $\geq$ winter (Fig. 4(a)Fig. 4(b)).

Canopy interactions varied annually for most elements: $\mathrm{NH}_{4}^{+}-\mathrm{N}$ and $\mathrm{H}_{2} \mathrm{PO}_{4}^{-}-\mathrm{P}$ uptake tended to decrease from $1992 / 1993$ to $1994 / 1995$ but the opposite trend applied to $\mathrm{K}-, \mathrm{Ca}-$ and $\mathrm{Mg}$-leaching. Total depusition of all elements was larger in 1993/1994 than in the other years (Table 4).

\subsection{Input-output budgets}

Tables $6-8$ present the results of seasonal, yearly and mean annual budgets calculated for each stand and for various rotation lengths, i.e. 20,40 or 60 years. All calculations were made considering two criteria for output from the soil, i.e. at 60 and 120 $\mathrm{cm}$ depth (only $60 \mathrm{~cm}$ depth for the 20-year-old stand).

Mean budgets of all elements except phosphorus were negative, but weathering inputs were not calculated.

Deficit or excess of nutrients varied over the 3 years. The deficit for most elements tended to be highest in 1994/1995 and the excess of $P$ was highest in $1993 / 1994$.

Annual average deficits for $\mathrm{N}, \mathrm{K}, \mathrm{Ca}$ and $\mathrm{Mg}$, at $60 \mathrm{~cm}$ depth, varied with stand age as follows: $20>40>60$. In the case of $S$ the picture was: $40>20>60$.

The most positive phosphorus budget occurred in the 60-year-old stand.

At $120 \mathrm{~cm}$ depth, the budgets were generally more negative than at $60 \mathrm{~cm}$ depth. In the 40 -year-old stand, this was true for all elements except nitrogen. but in the 60-year-old stand this was the case for all elements. These two stands differed tremendously as discussed previously in the qualitative approach: cation losses in the 40-year-old stand were related to $\mathrm{S}$ dynamics. whereas those in the 60-year-old stand were related to $\mathrm{N}$ dynamics.

Seasonal budgets showed that elements were mainly lost during the dormant season. At $60 \mathrm{~cm}$ depth, $\mathrm{N}$-deficits in the 20- and 40-year-old stands. for example. amounted respectively to 22.1 and 11.1 $\mathrm{kg} \mathrm{ha}^{-1}$ year $^{-1}$ in the dormant season but decreased to 4.3 and $2.4 \mathrm{~kg} \mathrm{ha}^{-1} \mathrm{year}^{-1}$ in the growing season. At $120 \mathrm{~cm}$. N. K, Mg and $\mathrm{S}$ losses were reduced on average by $80 \%$ or more and $\mathrm{Ca}$ losses by $40 \%$ during the growing season (Table 7 ).

\section{Discussion}

\subsection{Nutrient fluxes}

Mean wet deposition $(P t)$ was compared with the RENECOFOR network data (Ulrich and Lanier, 1994). $\mathrm{NH}_{4}^{+}-\mathrm{N}, \mathrm{NO}_{3}^{-}-\mathrm{N}, \mathrm{SO}_{4}^{2-}-\mathrm{S}$ and $\mathrm{K}^{+}$fluxes in the Beaujolais area were similar to mean values $(27$ sites) from this French monitoring network; $\mathrm{Ca}^{2+}$ and $\mathrm{Mg}^{2+}$ fluxes in the Beaujolais were lower. Specific comparison with the Douglas-fir site of this network (situated in the Morvan about $80 \mathrm{~km}$ further north), showed that rainfall input was generally lower in the Beaujolais, except for $\mathrm{K}^{+}$. Direct comparison between sites for total deposition (TD) was not possible but comparison of bulk throughfall indicated higher nitrogen and lower sulphur and 'base' cations in the present site. Values were very close to those from the Douglas-fir stand in Morvan for all elements, except for $\mathrm{K}^{+}$which was higher in the Beaujolais. 
Mean total deposition to stands was close to the values observed by Mohamed (1992) in two different adult Norway spruce stands in the Vosges mountains (France); the most significant differences were the higher $\mathrm{SO}_{4}^{2-}-\mathrm{S}, \mathrm{Cl}^{-}$and $\mathrm{H}^{+}$fluxes in the Vosges than in the Beaujolais. Lamersdorf and Meyer (1993) and Matzner and Meiwes (1994), who investigated Norway spruce stands in Germany, found much higher fluxes of $\mathrm{NH}_{4}^{+}-\mathrm{N}, \mathrm{NO}_{3}^{-}-\mathrm{N}, \mathrm{SO}_{4}^{2-}-\mathrm{S}$ and $\mathrm{Cl}^{-}$ than were observed in the present study or by Mohamed (1992) (2.5-3 times higher). Atmospheric deposition of $\mathrm{NH}_{4}^{+}-\mathrm{N}, \mathrm{NO}_{3}^{-}-\mathrm{N}, \mathrm{SO}_{4}^{2-}-\mathrm{S}, \mathrm{Cl}^{-}, \mathrm{K}^{+}$, $\mathrm{Ca}^{2+}$, and $\mathrm{Mg}^{2+}$ in Douglas-fir stands in the Netherlands (Draaijers et al., 1988) were much higher than inputs in France or Germany. Many reasons may explain these differences, one being the presence of pollutant sources in the close vicinity. The stands from the Netherlands were close to areas where animal husbandry was common and where emissions of $\mathrm{NH}_{3}$ were elevated. Temporal variations, as observed during the 3 year study period in the Beaujolais, or during longer studies (Matzner and Meiwes, 1994) can also affect data, as do local climatic conditions such as wind velocity, wind direction (Draaijers et al., 1988; Le Borgne, 1992) and time between rainfall events (Bastien, 1993). Moreover, even stands in similar situations, like the three stands in the present study, may differ as a result of stand development stage (Marques and Ranger, 1996).

Estimated contributions of dry deposition to total deposition of $\mathrm{N}, \mathrm{K}, \mathrm{Ca}$, and $\mathrm{Mg}$ were close to values obtained by Dambrine and Prevosto (1988) for Norway spruce stands in the Vosges mountains.

Nutrient fluxes were often highest at the forest floor level and decreased with soil depth following the pattern of water flux (Fig. 4(a), Fig. 4(b), Fig. 4(c) and Fig. 4(d)). This suggests that nutrient fluxes were mainly related to mass-flow. This was confirmed by the significant correlations between fluxes of most nutrients and water flux, indicating that variation of concentrations with time was less consequential than that of water flux (Table 9). This pattern of decreasing fluxes with soil depth has been frequently observed in many forest ecosystems for both qualitative (Feller, 1977; Edmonds et al., 1991; Ranger and Nys, 1994) or quantitative (Cole and Johnson, 1977, Mohamed and Ranger, 1994) fluxes and has been attributed to the reduction of water flux, to plant uptake, and to adsorption processes in the soil's mineral or organic phases.

In the present study, the elevated nutrient fluxes at the FF level were associated with nutrient release, i.e. litter leaching and/or organic matter mineralisation.

At the P-15 level, reduction in the 'base' cation fluxes was related to plant uptake while reduction of the $\mathrm{NH}_{4}^{+}-\mathrm{N}$ flux was considered to be associated with both plant uptake and nitrification. The large flux of nitrate in the upper soil layers was interpreted as an excess in the balance between production and plant uptake. The behaviour of $\mathrm{Al}^{3+}$ and $\mathrm{Si}$, which was similar to that of $\mathrm{NO}_{3}^{-}-\mathrm{N}$, was considered to be a consequence of the neutralisation of $\mathrm{H}^{+}$due to nitrification within the soil, by ion exchange or weathering reactions. All these aspects have been discussed in the qualitative approach of this study. It was pointed out that local mineralisation rather than nutrient transport from upper layers was the main process contributing to the quality of solutions throughout the soil profiles. Nevertheless, the behaviour of the $\mathrm{NO}_{3}^{-}-\mathrm{N}$ flux in the 20-year-old stand (Fig. 4(a)) suggests that $\mathrm{NO}_{3}^{-}-\mathrm{N}$ was transported

Table 9

Correlation coefficients between water and element fluxes at different depths in the soil (from mean data of stands)

\begin{tabular}{|c|c|c|c|c|c|c|c|c|c|c|c|c|c|c|c|}
\hline Flux & $\mathrm{NH}_{4}-\mathrm{N}$ & $\mathrm{NO}_{3}-\mathrm{N}$ & $\mathrm{SO}_{4}-\mathrm{S}$ & $\mathrm{H}_{2} \mathrm{PO}_{4}-\mathrm{P}$ & $\mathrm{K}$ & $\mathrm{Ca}$ & $\mathrm{Mg}$ & $\mathrm{Na}$ & $\mathrm{Mn}$ & $\mathrm{H}$ & $\mathrm{Al}$ & $\mathrm{Fe}$ & $\mathrm{Si}$ & $\mathrm{Cl}$ & TOC \\
\hline Forest floor & 0.49 & 0.59 & 0.61 & 0.58 & 0.53 & 0.65 & 0.67 & 0.60 & 0.67 & 0.73 & 0.68 & 0.86 & 0.72 & 0.79 & 0.79 \\
\hline P- 15 & 0.43 & 0.69 & 0.79 & 0.49 & 0.71 & 0.79 & 0.80 & 0.80 & 0.71 & 0.87 & 0.75 & 0.80 & 0.77 & 0.84 & 0.84 \\
\hline P-30 & 0.31 & 0.63 & 0.71 & 0.57 & 0.60 & 0.68 & 0.67 & 0.82 & 0.76 & 0.90 & 0.67 & 0.74 & 0.75 & 0.79 & 0.67 \\
\hline$P-60$ & 0.31 & 0.67 & 0.94 & 0.51 & 0.52 & 0.67 & 0.71 & 0.63 & 0.72 & 0.90 & 0.81 & 0.63 & 0.82 & 0.66 & 0.50 \\
\hline P- 120 & 0.43 & 0.62 & 0.82 & 0.44 & 0.86 & 0.87 & 0.87 & 0.77 & 0.81 & 0.93 & 0.82 & 0.68 & 0.81 & 0.72 & 0.60 \\
\hline
\end{tabular}

Forest floor, $n=109 ; \mathrm{P}-15,15 \mathrm{~cm}$ depth $(n=105) ; \mathrm{P}-30,30 \mathrm{~cm}$ depth $(n=98) ; \mathrm{P}-60,60 \mathrm{~cm}$ depth $(n=71) ; \mathrm{P}-120,120 \mathrm{~cm}$ depth $(n=60) ; r=0.32$ is significant at the $99 \%$ confidence level for $n=60$. 
from the P-15 level in autumn to the P-30 level in winter, at least in this stand. A more detailed analysis (Fig. 5) indicated that this transport from the P-15 to the P-30 level from one season to another occurred during the autumn/winter of 1994/1995 but was not observed during other periods.

At $\mathrm{P}-60$, nutrient fluxes were lower than in upper soil layers but were still high for some elements, especially in the 20-year-old stand. This was due to the high soil organic matter content in the 20-year-old stand which acted as a source of nutrients to the soil solution. Consequently, the nutrient output was large. This behaviour may be a consequence of two additional factors: (i) the high soil organic matter content itself and (ii) the decomposition of this soil organic matter, which was inherited from ancient land use. The young Douglas-fir plantation probably affected the stability of the pre-existing organic components in the soil and therefore resulted in imbalance within the soil. Another hypothesis is that this imbalance resulted from the clear-cutting of the ancient forest plantation (Likens et al., 1977; Kubin, 1995). Research on the history of this plot revealed that the land was used for crops from 1824 to 1930, then planted with Norway spruce, which was logged around 1970 when the current Douglas-fir stand was planted.

At P-120, fluxes were on average lower than at P-60 but most nutrient fluxes increased sharply in autumn-winter when large water fluxes reached this layer. Many mechanisms may account for this behaviour, such as changes in plant uptake or reduction in percolation rates, which would increase the residence time of solutions at the bottom of the soil (Ugolini et al., 1977). It was hypothesised in the qualitative approach that some nutrients were produced locally but doubt remained. This quantitative study provided more information. Fluxes that occurred simultaneously at P-15 and P-120 suggest that nutrient transport from the upper to the bottom levels did occur, but the simultaneous flux reduction at 60 $\mathrm{cm}$ led to two hypotheses: (i) solutions were transferred directly from P-30 to P-120 along preferential channels (e.g. dead roots) or (ii) nutrients were produced locally in the deepest horizon. The location of $\mathrm{SO}_{4}^{2-}-\mathrm{S}$ flux maximum at $\mathrm{P}-120$, particularly in the
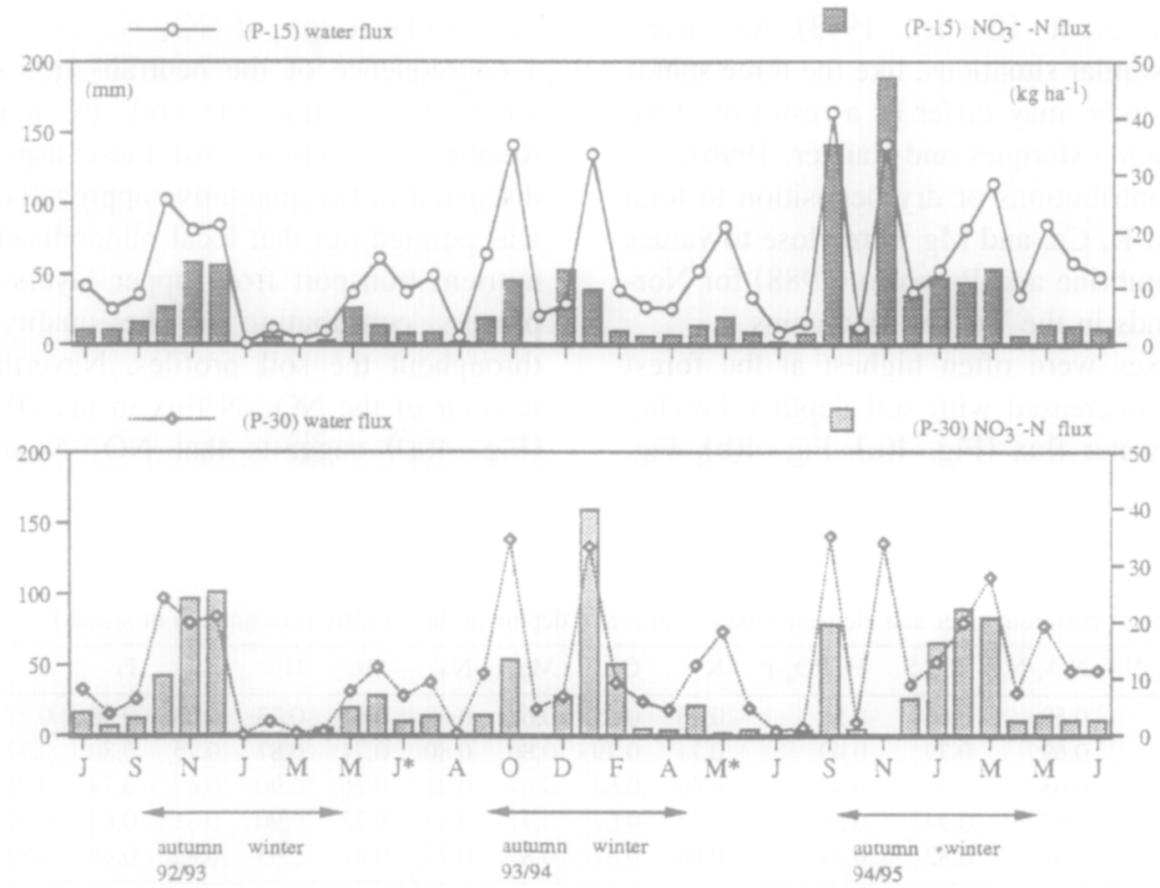

Fig. 5. Monthly water and $\mathrm{NO}_{3}-\mathrm{N}$ fluxes in the P-15 and P-30 lysimeters of the 20-year-old stand. As sampling was done every 4 weeks. there are some months where sampling occurred twice. 
40-year-old stand, seems to exclude the transport hypothesis (Fig. 6(a)). Marques et al. (1996) observed a high concentration of combined sulphur compounds (probably organic compounds) in the 'capillary' solutions collected at $120 \mathrm{~cm}$ in the 40 year-old stand, suggesting that organic matter components were destabilised locally. Doubts still remain regarding why $\mathrm{SO}_{4}^{2-}-\mathrm{S}$ was the dominant anion in the 40 -year-old stand and $\mathrm{NO}_{3}^{-} \mathrm{N}$ in the 60-year-old stand (Fig. 6(a)Fig. 6(b)). It was concluded in the qualitative approach that a reduced nitrification in the 40-year-old stand was probably the reason for this specific behaviour. This could also be related to different $\mathrm{N} / \mathrm{S}$ ratios in the organic pool of each stand as a consequence of differences in the former land occupation. The land of the 60-year-old stand had previously been used for crop production, since 1824 at least, whereas that of the 40 -year-old stand was abandoned land in 1824, since 1870 had been afforested with Norway spruce (two generations of about 40 years) and then with Douglas-fir, more recently, in 1955 .

In spite of unsatisfactory understanding of the actual processes, excess of nitrate or sulphate production over consumption led to large fluxes of 'base' cations at the P-120 level, which can be considered as unavailable for plants.

Solutions leaving the rooting zone of the 40- and 60 -year-old stands contained on average $4.9 \mathrm{mg}^{-1}$ of $\mathrm{Al}^{3+}$. As only total $\mathrm{Al}$ was measured, $\mathrm{Al}^{3+}$ probably represented about $2.5 \mathrm{mg} \mathrm{l}^{-1}$, according to the solution's pH (Driscoll, 1989). Analyses from a spring ( 11 monthly samplings) showed that the $\mathrm{pH}$ of surface waters was close to neutrality and their $\mathrm{Al}$ content was very low. This indicates that drainage water was neutralised somewhere in the subsoil, safeguarding the quality of surface waters (data not shown).

\subsection{Input-output budgets}

Atmospheric inputs into the Douglas-fir stands were among the medium range of values for forest ecosystems in France. Outputs were high and due to nutrient losses by seepage rather than to biomass immobilisation.

Annual variations in the nutrient budget were large during the 3 years of investigation. Annual deficits tended to be correlated with the amount of rainfall: $1992 / 1993<1994 / 1995$. Deficits were generally highest during the dormant season despite the lack of nutrient immobilisation by stands. This was related to large water fluxes, which typically belong to the cold season under temperate climates, and to drainage of elements at the bottom of the soil (Fig. 4(a), Fig. 4(b), Fig. 4(c) and Fig. 4(d)). Atmospheric inputs were totally removed by seepage; in addition, a large amount of nitrate produced within the soil was drained away and this occurred indistinctly throughout the dormant season.

Nutrient outputs during the growing season were more strongly related to stand immobilisation than to drainage, in the 40- and 60-year-old stands (Table 7). Nevertheless, the reverse occurred in the younger stand because of its specific soil dynamics as discussed before. Nitrate losses during the growing season suggest that nitrification largely exceeded forest stand requirements. Negative cation budgets were just a consequence of the nitrogen dynamics. More sulphate was lost through drainage than through immobilisation irrespective of stand age, and this was due to a relatively high atmospheric input coupled to a low immobilisation rate.

Theoretical budgets assuming forest rotation lengths of 20,40 or 60 years were calculated for output levels at 60 and $120 \mathrm{~cm}$ depth. Two harvesting systems were taken into account: harvesting of stems only or whole tree harvesting (biomass and nutrient content data were presented in detail in Ranger et al., 1995).

For a 60 year rotation (stem only harvesting), at $60 \mathrm{~cm}$ depth, the nutrient deficit (atmospheric input - immobilisation - drainage) amounted to $670 \mathrm{~kg}$ $\mathrm{N}, 694 \mathrm{~kg} \mathrm{~K}, 663 \mathrm{~kg} \mathrm{Ca}, 296 \mathrm{~kg} \mathrm{Mg}$ and $346 \mathrm{~kg} \mathrm{~S}$ (Table 8). Balancing this budget would require an annual ecosystem $\mathrm{N}$ accumulation of $11 \mathrm{~kg}$ and an input by weathering of about $12 \mathrm{~kg} \mathrm{~K}, 11 \mathrm{~kg} \mathrm{Ca}, 5$ $\mathrm{kg} \mathrm{Mg}$ and $6 \mathrm{~kg} \mathrm{~S} \mathrm{ha}^{-1}$. $\mathrm{N}$ - and S-sources are very difficult to estimate since they are related to the behaviour of microorganisms, therefore only internal soil fluxes of $\mathrm{K}, \mathrm{Ca}$, and $\mathrm{Mg}$ are discussed here. Bonneau et al. (1991) and Mohamed (1992) estimated weathering rates, in soils with a similar 'base' cation content, at $6.8 \times 10^{-5} \mathrm{~kg} \mathrm{~K}, 2 \times 10^{-4} \mathrm{~kg} \mathrm{Ca}$ and $5 \times 10^{-5} \mathrm{~kg} \mathrm{Mg} \mathrm{ha}^{-1}$ year $^{-1}$. Applying these rates to the total amount of elements in the fine earth 
of the soils (Table 1) yields a weathering flux of 10.5 $\mathrm{kg} \mathrm{K} .0 .6 \mathrm{~kg} \mathrm{Ca}$, and $1.2 \mathrm{~kg} \mathrm{Mg}$ (assuming the stones did not contribute to the weathering flux). Not enough data were available to confirm weathering fluxes but preliminary results suggest that estimated values were reasonable for $\mathrm{K}$ but not for $\mathrm{Ca}$ and $\mathrm{Mg}$ (Ezzaìm et al., 1996). It was thus hypothesised that the weathering flux was sufficient to conpensate for $\mathrm{K}$ deficits.

(a)
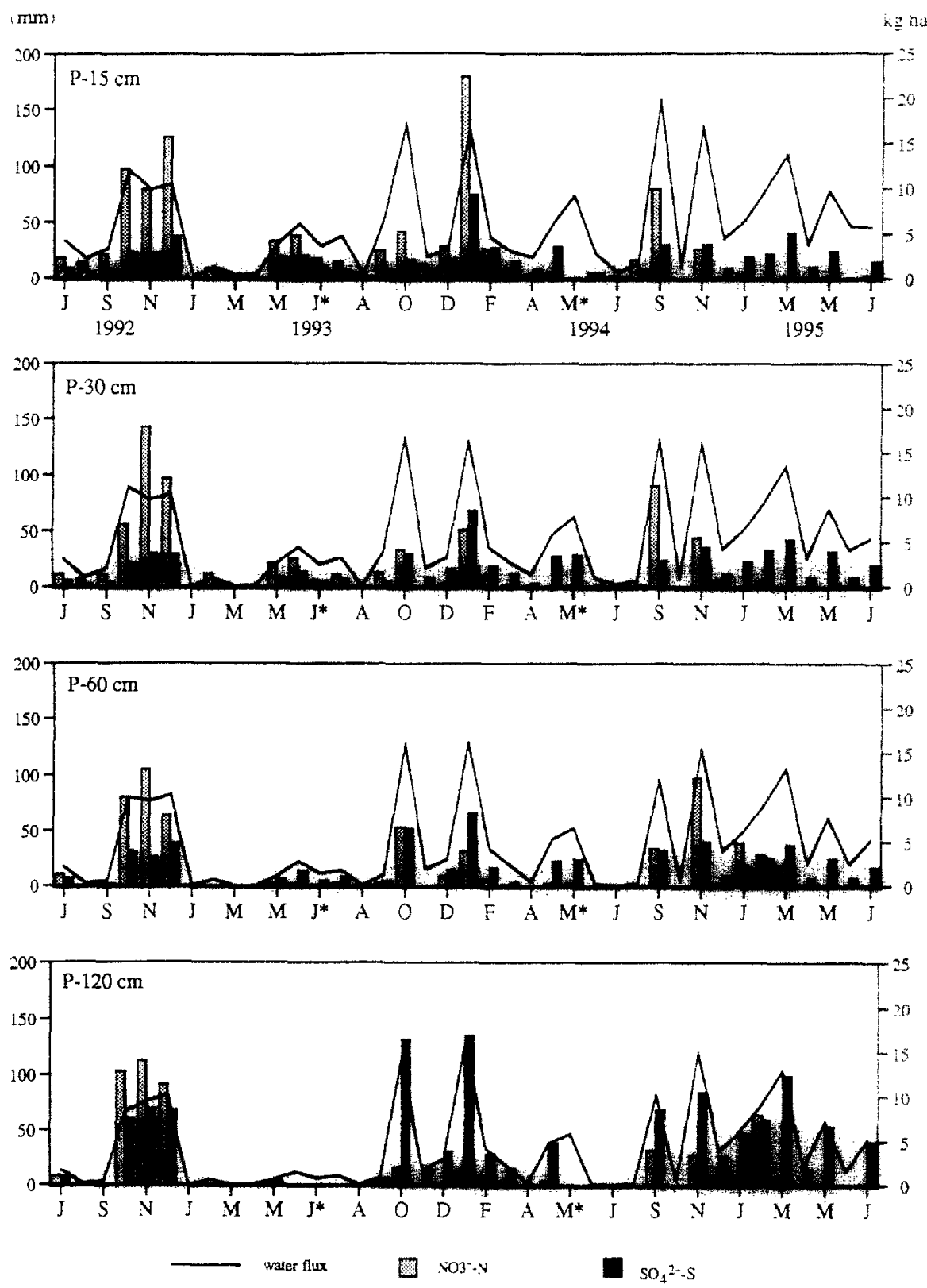

Fig. 6. (a) Temporal variations of nitrate, sulphate and estimated water fluxes in the plate lysimeters of the 40 -year-old stand. As sampling was done every 4 weeks, there are some months where sampling occurred twice. (b) Temporal variations of nitrate, sulphate and estimated water fluxes in the plate lysimeters of the 60-year-old stand. As sampling was done every 4 weeks, there are some months where sampling occurred twice. 
(b)
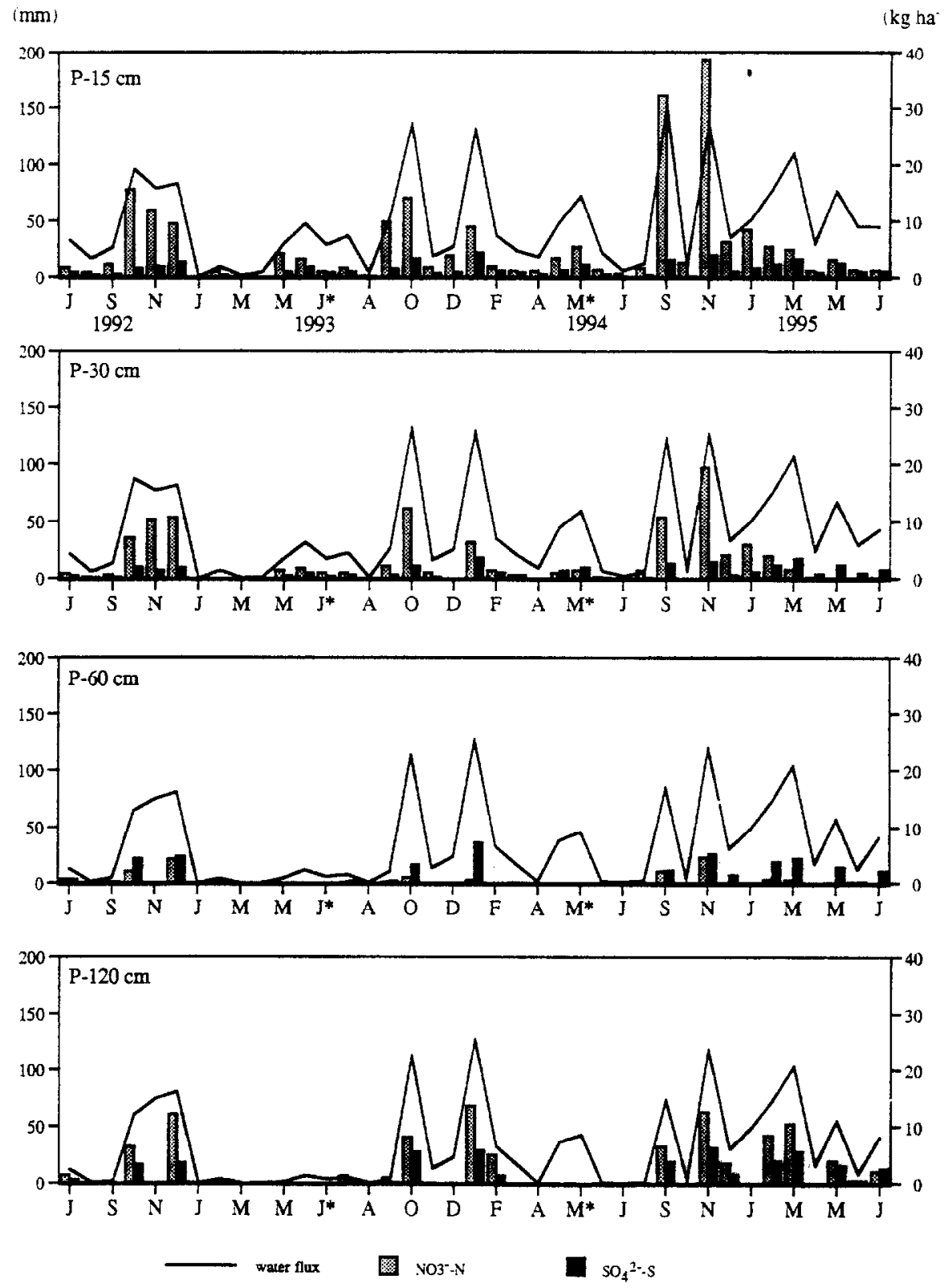

Fig. 6 (continued).

Conservative values for $\mathrm{Ca}$ and $\mathrm{Mg}$ weathering fluxes were adopted, i.e. $3.5 \mathrm{~kg} \mathrm{Ca} \mathrm{ha}^{-1}$ year $^{-1}$ and $2.5 \mathrm{~kg}$ $\mathrm{Mg} \mathrm{ha}^{-1}$ year $^{-1}$. Even with this conservative hypothesis, deficits at the end of a 60 year rotation amounted to $450 \mathrm{~kg} \mathrm{Ca}$ and $140 \mathrm{~kg} \mathrm{Mg}$. This means that the soil has lost about $50 \%$ of the $\mathrm{Ca}$ and $42 \%$ of the $\mathrm{Mg}$ present in the initial pool of available nutrients over the last 60 years.

For a 60 year rotation, at $120 \mathrm{~cm}$ depth, nutrient losses amounted to $798 \mathrm{~kg} \mathrm{~N}, 991 \mathrm{~kg} \mathrm{~K}, 815 \mathrm{~kg} \mathrm{Ca}$, $346 \mathrm{~kg} \mathrm{Mg}$ and $1380 \mathrm{~kg} \mathrm{~S}$. Annual weathering fluxes necessary for compensating these deficits should be 
Table 10

Estimated nutrient budgets for a second 60-year Douglas-fir rotation at the Beaujolais site (data expressed in $\mathrm{kg} \mathrm{ha}^{-1}$ )

\begin{tabular}{|c|c|c|c|c|c|c|}
\hline & $\mathrm{N}$ & $S$ & $\mathrm{P}$ & $\mathrm{K}$ & $\mathrm{Ca}$ & $\mathrm{Mg}$ \\
\hline \multicolumn{7}{|l|}{ Stem only hariesting } \\
\hline Total input & 1141.3 & 747.2 & 97.8 & 208.2 & 339.9 & 60.9 \\
\hline Total immobilisation & 402.4 & 26.0 & 32.7 & 197.1 & 262.4 & 34.6 \\
\hline Total drainage fluxes & 11353 & 1215.5 & 32.3 & 404.5 & 512.3 & 241.5 \\
\hline Budget for the forest rotation & -396.4 & -494.4 & 32.8 & -393.4 & -434.8 & -215.2 \\
\hline Estimated total weathering & & & & 630 & 210 & 150 \\
\hline Budget including weathering input & & & & 236.6 & -224.8 & -6.5 .2 \\
\hline \multicolumn{7}{|l|}{ Whole tree hartesting } \\
\hline Total input & 1141.3 & 747.2 & 97.8 & 208.2 & 339.9 & 60.9 \\
\hline Total immobilisation & 852.0 & 108.0 & 72.0 & 346.0 & 648.0 & 70.0 \\
\hline Total drainage fluxes & 1135.3 & 1215.5 & 32.3 & 404.5 & 512.3 & $2+1.5$ \\
\hline Budget for the forest rotation & -846.0 & -576.4 & -6.5 & -542.3 & -820.4 & -250.6 \\
\hline Estimated total weathering & & & & 6.30 & 210 & 150 \\
\hline Budget including weathering input & & & & 87.7 & -610.4 & -100.6 \\
\hline
\end{tabular}

$16.5 \mathrm{~kg} \mathrm{~K}, 13.6 \mathrm{~kg} \mathrm{Ca}$ and $5.8 \mathrm{~kg} \mathrm{Mg} \mathrm{ha}^{-1} \mathrm{year}^{-1}$. Compared with the budget calculated at $60 \mathrm{~cm}$, deficits at $120 \mathrm{~cm}$ depth did not increase too much. Assuming fluxes twice as large as fluxes at $60 \mathrm{~cm}$ depth, the deficit of Mg may be almost balanced but not that of $\mathrm{Ca}$, of which the amount initially available would be depleted by $61 \%$.

Shorter rotation lengths may deplete 'base' cations dramatically; estimated deficits (at a $60 \mathrm{~cm}$ depth) would amount to $26 \mathrm{~kg} \mathrm{~K}, 19 \mathrm{~kg} \mathrm{Ca}$ and $9 \mathrm{~kg} \mathrm{Mg}$ $\mathrm{ha}^{-1}$ year $^{-1}$ for a 20 year rotation, and to $19 \mathrm{~kg} \mathrm{~K}$, $15 \mathrm{~kg} \mathrm{Ca}$ and $7 \mathrm{~kg} \mathrm{Mg} \mathrm{ha}^{-1}$ year $^{-1}$ for a 40 year rotation (Table 8 ). These estimations agree with previous works with respect to the negative impact of short rotations on nutrient budgets (Switzer and Nelson, 1973; Kimmins, 1974, 1977; Leaf, 1979), and may be more drastic since losses due to clearcutting and regeneration operations were not estimated (Likens et al., 1977; Dyck et al.. 1994; Kubin. 1995).

Deficits were very much higher for whole tree harvesting (WTH) than for stem-only harvesting (SH) as a consequence of the huge amount of nutrients immobilised in the tree crown (Ranger et al., 1995). The cumulation of increased removal from harvesting and a shorter rotation led to very high nutrient demands. The weathering flux required for compensating the $\mathrm{Ca}$-deficit in a 20 year rotation associated with WTH would be 1.6 times greater than under $\mathrm{SH}$ (Table 8).
The nutrient budget for a new identical forest rotation (SH vs. WTH) was simulated to estimate the soil depletion during the next 60 years (Table 10). The following assumptions were made:

1. the impact of the early stage of development on organic matter mineralisation would be more or less stabilised and the drainage flux at $60 \mathrm{~cm}$ depth was estimated as the weighted average values observed today in the 40 - and 60-year-old stands;

2. atmospheric inputs and stand immobilisation would remain similar to those of the first rotation. Deficits under SH would amount to $395 \mathrm{~kg} \mathrm{~K}, 435$ $\mathrm{kg} \mathrm{Ca}$ and $215 \mathrm{~kg} \mathrm{Mg}$, per harvesting cycle, representing annual losses of $6.6 \mathrm{~kg} \mathrm{~K}, 7.2 \mathrm{~kg} \mathrm{Ca}$ and 3.6 $\mathrm{kg} \mathrm{Mg} \mathrm{ha}{ }^{-1}$. The weathering flux values assumed above should be able to compensate for $\mathrm{K}$ losses, barely compensate for $\mathrm{Mg}$ losses but cannot compensate for $\mathrm{Ca}$ losses. The $\mathrm{Ca}$ deficit at the end of the second Douglas-fir rotation would amount to about $225 \mathrm{~kg}$. The initial available storage before the first rotation, which was estimated at $905 \mathrm{~kg}$ Ca $(455 \mathrm{~kg}$ in the present storage plus $450 \mathrm{~kg}$ lost during the first rotation) would be reduced to $230 \mathrm{~kg} \mathrm{Ca}(455$ $\mathrm{kg}$ in the present storage minus $225 \mathrm{~kg}$ lost during the second rotation). Total losses during the 120 year period represent $75 \%$ of the initial storage.

With WTH, the imbalance of the ecosystem would be almost doubled for $\mathrm{N}, \mathrm{K}$ and $\mathrm{Ca}$ and would even extend to $P$ whose budget was positive during the 
first rotation. The weathering fluxes would barely compensate for the $\mathrm{K}$ and $\mathrm{Mg}$ deficits and in no way compensate for the $\mathrm{Ca}$ deficit. The present available Ca-storage of about $455 \mathrm{~kg}$ would be sold out. The $\mathrm{Ca}$ nutrition of the next generation would undoubtedly be affected.

If the budget results are confirmed after evaluation of the weathering fluxes (work in progress), severe changes would occur in the soil function whatever silvicultural scenario is adopted. The following changes in soil fertility would occur:

1. reduction of available $\mathrm{Ca}$ pool;

2. desaturation of the soil exchange complex, expressed as an enhancement of $\mathrm{Al}$ retention and a reduction of 'base' cations $(\mathrm{BC})$ on the exchange sites;

3. decrease of $\mathrm{BC} / \mathrm{Al}$ ratios in the soil solution accompanied by the well known consequences for plant nutrition (Rost-Siebert, 1983; Huttermann and Ulrich, 1984; Boudot et al., 1995).

\section{Conclusions}

The pattern of fluxes obtained after 3 years of observation did not give a definitive picture for the behaviour of this Douglas-fir ecosystem. Owing to large temporal variations, monitoring should continue for several years to validate the present trends and to reduce the weight of singular climatic years.

The chronosequence approach proved to be a very useful tool to discriminate differences in the plantsoil relationships related to stand development. This was true in spite of uncertainties regarding the complete similarity of plot characteristics at time zero.

Differences in historical land usage of the plots certainly affected the dynamics of elements in the soil today. However, it is difficult to determine the extent of this influence.

Negative input-output budgets for N, S, Ca and to a lesser extent for $\mathrm{Mg}$, suggest that the soil chemical dynamics were imbalanced, probably because of the impact of the present vegetation. High rates of nitrification and organic sulphur oxidation indirectly induced strong losses of nutrients out of the rooting zone. Soil acidification results more from excess nitrification throughout the soil profile than from external acidic deposition. An unsolved ques- tion is: why was sulphur oxidation the acidifying source in the 40-year-old stand and nitrification in the 60-year-old stand?

Negligible impact on surface water chemistry was determined by monitoring a spring but requires confirmation by more extensive investigations.

Stands presently had a satisfactory health status, identified from direct morphological observations and foliar analysis (Ranger et al., 1995). Nutrient supply was large enough to sustain the present high production rate, but negative budgets suggest that this ecosystem is not stable and that long-term productivity cannot be ensured if a similar trend occurs at the next rotation.

The budget deficits revealed that the present stand growth is obtained at the expense of the soil organic matter compartment, thereby promoting soil desaturation which may seriously compromise future forest growth. Extrapolation of the budget to the next rotation is merely speculative. The trend of decrease in the budget deficit with stand age suggests that the effect of the vegetation change will be reduced at the next rotation but the impact of stand development may remain.

The present results did not lead to definitive conclusions about the impact of high productive Douglas-fir stands on soil dynamics and surface water quality. Nevertheless, the present trend indicates a very high loss of 'base' cations from the soil profile, which may decrease soil fertility within a rather short time scale.

A sustainable management strategy for these Douglas-fir stands should exclude whole tree harvesting as this would quickly lead to large soil nutrient deficiencies. Silvicultural practices like remnant windrowing, remnant burning or full-tree skidding would lead to the same result and the maintenance of sustainability would require nutrient input by fertilisation.

\section{Acknowledgements}

We would like to thank the technical staff of the 'Cycles biogéochimiques' research team for assistance, Dominique Gelhaye for managing the field work, Séverine Bienaime, Louisette Gelhaye and Benôt Pollicr for laboratory measurements; the for- 
est managers, the 'Office National des Forêts', and particularly G. Poly and B. Jobard for providing facilities during investigation and sampling; Philip Butler for revising the English; and the 'Ministère de l'Agriculture, Division de l'Espace Rural et de la Forêt', for providing the financial support for this research project.

\section{References}

Aussenac, G. and Boulangeat, C., 1980. L interception des précipitations et évapotranspiration réelle dans des peuplements de feuillu (Fagus siliatica L.) et de résineux (Pseudotsuga menziesii (Mirb.) Franco). Ann. Sci. For., 37: 91-107.

Bastien, J., 1993. Modélisations des concentrations et flux en éléments chimiques présents dans les pluies et pluviolessivats en fonction de facteurs météorologiques. Université Nancy I/INRA, D.E.S.S. d'Ingénierie mathématique et d'outils informatiques, Nancy, 50 pp.

Beets, P.N.. Terry, T.A. and Manz, J., 1994. Management systems for sustainable productivity. In: W.J. Dyck, D.W. Cole and N.B. Comerford (Editors), Impacts of Forest Harvesting on Long-term Site Productivity. Chapman and Hall, London, pp. 219-246.

Bonneau, M., Dambrine, E. and Ranger. J., 1991. Apports acides et cycle des cations dans des pessières du Nord-Est: interêt de bilans saisonniers. Sci. Sol. 21: 125-145.

Boudot, J.-P., Becquer, T., Merlet, D., Rouiller, J., Ranger, J.. Dambrine, E. and Mohamed, D.A., 1995. Potential role of aluminium toxicity in nutrient deficiencies as related to forest decline: an assessment of soil solution data from the Vosges mountains. In: G. Landmann and M. Bonneau (Editors), Forest Decline and Atmospheric Deposition Effects in the French Mountains. Springer, Berlin/Heidelberg, pp. 270-285.

Breda, N., 1994. Analyse du fonctionnement hydrique des chênes sessile (Quercus petraea) et pédonculé (Quercus robur) en conditions naturelles; effets des facteurs du millieu et de l'éclaircie, Université Nancy I/INRA, Thèse de Doctorat en Biologie Forestière, Nancy, 59 pp. + annexes.

Bredemeier, M., 1988. Forest canopy transformations of atmospheric deposition. Water, Air, Soil Pollut., 40: 121-138.

Cole, D.W. and Johnson, D.W., 1977. Atmospheric sulfate additions and cations leaching in a Douglas Fir ecosystem. Water Resour. Res.. 13: 313-317.

Dambrine, E. and Prevosto, B.. 1988. Flux des éléments minéraux dans un écosystème forestier d'altitude soumis à la pollution atmosphérique, relation avec le dépérissement. Rapp. Sci. DEFORPA, Décembre 1988.

Draaijers, G.P.J., Ivens, W.P.M. and Bleuten, W.. 1988. Atmospheric deposition in forest edges measured by monitoring canopy throughfall. Water, Air, Soil Pollut, 42: 129-136.

Driscoll. C.T.. 1989. The chemistry of aluminum in surface waters. In: G. Sposito (Editor), The Environmental Chemistry of Aluminum. CRC Press, Boca Raton, pp. 242-273.
Duchaufour, P. and Bonneau, M.. 1959. Une methode nouvelle du dosage du phosphore assimilable dans les sols forestiers. Bull. Assoc. Française pour l'Etude du Sol, 4: 193--198.

Dyck, W.J., Cole, D.W. and Comerdorf, N.B. (Editors), 1994. Impacts of forest harvesting on long-term site productivity. Chapman and Hall, London, $368 \mathrm{pp}$.

Edmonds, R.L., Thomas, T.B. and Rhodes, J.J., 1991. Canopy and soil modification of precipitation chemistry in a temperate rain forest. Soil Sci. Soc. Am. J., 55: 1685-1693.

Ezzaïm. A.. Turpault. M.-P. and Ranger, J., 1996. Répartition des nutriments dans un sol brun acide développé sur tuf́ (Beaujolais, France). Conséquences pour l'évolution de la fertilité minérale à long terme. Annales des Sciences Forestières, in press.

Feger, K.H., 1988. Historical changes in catchment use. In: H. Barth (Editor), Effects of land use in catchments on the acidity and ecology of natural surface waters. CEC. Air Pollut. Rep.. 13: $65-74$.

Feller, M.C.. 1977. Nutrien movement through western hemlock-western redcedar ecosystems in southwestern British Columbia. Ecology. 58: 1269-1283.

Granier, A., 1987. Evaluation of transpiration in a Douglas-fir stand by means of sap flow measurements. Tree Physiol. 3 : 309-320.

Huttermann, A. and Ulrich. B.. 1984. Solid phase-solution-root interactions in soils subjected to acid deposition. Phil. Trans. R. Soc. London, Ser. B, 305: 353-368.

Kimmins, J.P., 1974. Sustained yield. timber mining, and the concept of ecological rotation: a British Columbian view. For. Chron.. Feb.: 27-31.

Kimmins, J.P., 1977. Evaluation of the consequences for future tree productivity of the loss of nutrients in whole-tree harvesting. For. Ecol. Manage., 1: 169-183.

Kubin. E., 1995. The effect of clear cutting. waste wood collecting and site preparation on the nutrient leaching to groundwater. In: L.O. Nilsson, R.F. Huittl and U.T. Johansson (Editors), Proc. of the CEC/IUFRO Symp. on Nutrient Uptake and Cycling in Forested Ecosystems, Halmstad, Sweden, 7-10 June 1993, Kluwer, Dordrecht, pp. 661-670.

Lamersdorf, N. and Meyer. M.. 1993. Nutrient cycling and acidification of a northwest German forest site with high atmospheric nitrogen deposition. For. Ecol. Manage.. 62: 323--354.

Leaf, A.L. (Editor), 1979. Proc. of Symp. on Impact of Intensive Harvesting on Forest Nutrient Cycling, School of Forestry. State University of New York, Syracuse, $421 \mathrm{pp}$.

Le Borgne. A., 1992. Étude de la composition chimique des precipitations à decouvert cn relation avec les types de temps et le climat de pollution. Le cas de la station d'Aubure (Vosges). Université de Paris I, Mémoire de D.E.A. de Géographie et de l'Environnement Global, Paris, $50 \mathrm{pp}$.

Likens, G.E.. Bormann, F.M., Pierce, R.S.. Eaton. J.S. and Jonhson, N.M., 1977. Biogeochemistry of a Forested Ecosystem. Springer, New York, 146 pp.

Lovett, G.M. and Lindberg, S.E., 1984. Dry deposition and canopy exchange in a mixed oak forest as determined by analysis of throughfall. J. Appl. Ecol., 21: 1013-1027.

Marques, R. and Ranger, J.. 1996. Nutrient dynamics in a chronosequence of Douglas-fir (Pseudotsuga menziesii (Mirb). 
Franco) stands on the Beaujolais Mounts (France). 1. Qualitative approach. For. Ecol. Manage., in press.

Marques, R.. Ranger. J., Gelhaye, D., Pollier, B., Ponette, Q. and Godert, O., 1996. Comparison of chemical composition of soil solutions collected by zero-tension plate lysimeters with those from ceramic-cup lysimeters in a forest soil. Eur. J. Soil Sci., 47: $407-417$.

Matzner, E. and Meiwes, K.J., 1994. Long-term development of element fluxes with bulk precipitation and throughfall in two German forests. J. Environ. Qual., 23: 162-166.

Mohamed, A.D., 1992. Rôle du facteur édaphique dans le fonctionnement biogéochimique et l'état de santé de deux pessières vosgiennes. Effet d'un amendement calci-magnésien. Université de Nancy I/INRA-CRF, Thèse Doctorat, Nancy, $206 \mathrm{pp}$.

Mohamed, A.D. and Ranger, J., 1994. The biogeochemical cycle in a healthy and highly productive Norway spruce (Picea abies) ecosystem in the Vosges, France. Can. J. For. Res., 24: 839-849.

Pagc, G., 1970. Some effects of conifer crops on soil properties. Comm. For. Rev., 47: 52-62.

Ranger, J. and Nys, C., 1994. The effect of spruce (Picea abies Karst.) on soil development: an analytical and experimental approach. Eur. J. Soil Sci., 45: 193-204.

Ranger, J., Marques, R., Colin-Belgrand, M. and Flammang, N., 1995. The dynamics of biomass and nutrient accumulation in a Douglas-fir (Pseudotsuga menziesii Franco) stand studied using a chronosequence approach. For. Ecol. Manage.. 72: 167183.
Rost-Siebert, K., 1983. Aluminium Toxizität und Toleranz am Keimpflanzen von Fichte und Buche. Allgem. Forstz., 5: 686-689.

Soil Survey Staff, 1975. Soil Taxonomy. USDA Soil Conservation Service. US Government Printing Office. Washington, DC, 754 pp.

Switzer. G.L. and Nelson, L.E., 1973. Maintien de la productivite avec des revolutions courtes. In: Colloque International sur l' Utilisation des Engrais en Forêt, FAO/IUFRO, Paris, 3-7 December 1973, pp. 355-381.

Ugolini, F.C., Minden, R., Dawson, H. and Zachara, J., 1977. An example of soil processes in the Abies amabilis zone of Central Cascades, Washington. Soil Sci., 124: 291-302.

Ulrich, B., 1983. Interaction of forest canopies with atmospheric constituents: $\mathrm{SO}_{2}$, alkali and earth alkali cations and chloride. In: B. Ulrich and J. Pankrath (Editors), Effects of Accumulation of Air Pollutants in Forest Ecosystems. D. Reidel, Dordrecht, pp. 33-45.

Ulrich, E. and Lanier, M., 1994. Depots atmospheriques et concentrations des solutions du sol (sous reseau Cataenat) Rapport scientifique sur l'année 1993. Fontainebleau, Office National des Forêts-Département des Recherches Techniques, 117 pp.

Villette, S., 1994. Etablissement du bilan hydrique sur une chronoséquence de peuplements de Douglas (Pseudotsuga menziesii (Mirb.) Franco) du Beaujolais. Essai de modélisation. ENITA/INRA-CRF. Nancy, Mémoire de fin d'études. $50 \mathrm{pp}$. 